\title{
Sink or float: microtextural controls on the fate of pumice deposition during the 2012 submarine Havre eruption
}

\author{
Samuel J. Mitchell ${ }^{1}$ (D) Kristen E. Fauria ${ }^{2} \cdot$ Bruce F. Houghton $^{3} \cdot$ Rebecca J. Carey $^{4}$
}

Received: 23 July 2021 / Accepted: 29 September 2021 / Published online: 30 October 2021

(c) The Author(s) 2021

\begin{abstract}
Silicic submarine volcanic eruptions can produce large volumes of pumices that may rise buoyantly to the ocean surface and/or sink to the seafloor. For eruptions that release significant volumes of pumice into rafts, the proximal to medial submarine geologic record is thus depleted in large volumes of pumice that would have sedimented closer to source in any subaerial eruption. The 2012 eruption of Havre volcano, a submarine volcano in the Kermadec Arc, presents a unique opportunity to study the partitioning of well-constrained rafted and seafloor pumice. Macro- and microtextural analysis was performed on clasts from the Havre pumice raft and from coeval pumiceous seafloor units around the Havre caldera. The raft and seafloor clasts have indistinguishable macrotextures, componentry, and vesicularity ranges. Microtextural differences are apparent as raft pumices have higher vesicle number densities $\left(10^{9} \mathrm{~cm}^{-3} \mathrm{vs} .10^{8} \mathrm{~cm}^{-3}\right)$ and significantly lower pore space connectivity $(0.3-0.95$ vs. 0.9-1.0) than seafloor pumices. Porosity analysis shows that high vesicularity raft pumices required trapping of gas in the connected porosity to remain afloat, whereas lower vesicularity raft pumices could float just from gas within isolated porosity. Measurements of minimum vesicle throat openings further show that raft pumices have a larger proportion of small vesicle throats than seafloor pumices. Narrow throats increase gas trapping as a result of higher capillary pressures acting over gas-water interfaces between vesicles and lower capillary number inhibiting gas bubble escape. Differences in isolated porosity and pore throat distribution ultimately control whether pumices sink or float and thus whether pumice deposits are preserved or not on the seafloor.
\end{abstract}

Keywords Submarine volcanism $\cdot$ Pumice raft $\cdot$ Microtextures $\cdot$ Connected porosity $\cdot$ Pore throats $\cdot$ Gas trapping

\section{Introduction}

Physical volcanology is rooted in the interpretation of volcanic products [Cashman and Sparks 2013; Martí et al. 2018]. Our understanding of changes in eruptive styles, clast transportation and deposition mechanisms, and key physical parameters

Editorial responsibility: C. Cimarelli

This paper constitutes part of a topical collection: What pyroclasts can tell us

Samuel J. Mitchell

sam.mitchell@bristol.ac.uk

1 School of Earth Sciences, University of Bristol, Wills Memorial Building, Queens Rd, Bristol BS8 1RJ, UK

2 Department of Earth and Environmental Sciences, Vanderbilt University, Nashville, TN 37240, USA

3 Department of Earth Sciences, University of Hawai'i at Mānoa, Honolulu, HI 96822, USA

4 School of Natural Sciences, University of Tasmania, Hobart, TAS 7001, Australia (e.g., mass eruption rate and total eruptive volume) is highly dependent on accurate analysis and interpretation of deposits that form orderly stratigraphic sequences [Pyle 1989; Houghton and Carey 2015]. While most volcanism occurs in the ocean, submarine-erupted volcanic sequences remain less studied than their subaerial counterparts [Rubin et al. 2012; Cas and Simmons 2018]. In the deep-sea environment, large volumes of freshly erupted material can be missing from the proximal to medial geologic record due to the dispersal of clasts as pumice rafts during eruptions [Bryan et al. 2012; Carey et al. 2018] and the complex nature of submarine ash dispersal and settling [Stewart and McPhie 2004]. Conducting studies solely on the preserved proximal seafloor deposits may therefore significantly underestimate eruption volume and mass eruption rate, skewing our understanding of deep-sea volcanic eruptive styles, dynamics, and magma production rates on the seafloor. To date, there has been no study that directly and quantitatively compares clast textures within raft and seafloor deposits sampled in situ through direct submersible operation from the same submarine eruption and/or eruptive vent. 


\section{Pumice rafts}

Pumice rafts can be utilized to trace and track submarine volcanic activity back to its eruptive source [Vaughan et al. 2007; Carey et al. 2014], are a primary hazard associated with deep-sea volcanic eruptions as they can obstruct ship traffic and potentially damage vessels [Gass et al. 1963; Bryan et al. 2004], and are important in the establishing of endemic marine ecosystems and its ocean surface movement [Bryan et al. 2004]. The low density of gas-filled pumice relative to seawater permits pumice to remain afloat for many months to years after an eruption, and thus, pumice can be dispersed thousands of kilometers away from the source [Bryan et al. 2004; Bryan et al. 2012; Jutzeler et al. 2014; Carey et al. 2018]. Large rafts of pumice have been documented throughout history and used to identify submarine eruptions (e.g., Kolumbo 1650, South Sandwich Islands 1962, and Tonga 2002 [Risso et al. 2002; Bryan et al. 2004; Nomikou et al. 2014]).

Satellite tracking of rafts presents the opportunity to identify and study new submarine eruptions and can motivate rapid response ship-based exploration [Jutzeler et al. 2014; Brandl et al. 2019; Mittal and Delbridge 2019; Whiteside et al. 2021]. The 2012 submarine eruption at Havre volcano, Kermadec Ridge, New Zealand, is an example of how raft identification via remote sensing led to a swift, extensive, and ongoing, research effort into a large deep-sea eruption [Carey et al. 2014]. A study of the raft and seafloor volumes from the 2012 Havre eruption highlighted that over $70 \%$ of eruptive material was dispersed away from source in a voluminous pumice raft and is not preserved close to the volcano [Carey et al. 2018]. Extensive seafloor research, based mainly on a 2015 research cruise, has allowed us to constrain different parts of the eruptive history from raft observations, seafloor deposits, and clast analyses [Carey et al. 2018; Ikegami et al. 2018; Manga et al. 2018a; Mitchell et al. 2019; Murch et al. 2019a; Murch et al. 2019b]. However, to understand and constrain accurately processes during submarine pumice-producing eruptions, and to further understand what makes pumice float or sink, it is imperative that we combine observations with detailed microtextural analyses of pyroclasts from both raft and seafloor environments. The following study of the 2012 Havre raft and seafloor pumice does as such.

\section{Pumice-bearing units of the 2012 submarine Havre eruption}

The July 2012 submarine eruption of Havre volcano, on the Kermadec Ridge, produced $1.5-2 \mathrm{~km}^{3}$ of rhyolite products $\left(70-72 \mathrm{wt} \% \mathrm{SiO}_{2}\right)$ in the form of lava flows, lava domes, pumice-rich units, and ash-bearing units [Fig. 1] [Carey et al. 2018]. This study focuses on the pumice-bearing units erupted from the main 900-m-deep vent (the pumice raft, RP; a giant pumice unit, GP; and an ash-lapilli-block deposit proximal to the vent, ALB).

The pumice raft (RP) is estimated from satellite imagery to have been produced from the main vent over a period of $21 \mathrm{~h}$ [Fig. 2a], had an estimated bulk volume of $1.2( \pm 0.2)$ $\mathrm{km}^{3}$, and was estimated to be erupted at a mass eruption rate (MER) of $\sim 10^{7} \mathrm{~kg} \mathrm{~s}^{-1}$ [Carey et al. 2014 2018]. A seafloor deposit of giant pumiceous blocks (GP) with decimeter to $9 \mathrm{~m}$ diameters [Fig. 2d-f] was inferred to have erupted from the same vent as the raft due to the direction of clast dispersal and based on similar geochemistry and bulk porosities of clasts in deposits [Carey et al. 2018]. The GP unit has a bulk volume of at least $0.1 \mathrm{~km}^{3}$ and covers at least $35 \mathrm{~km}^{2}$ of the caldera floor (as mapped) [Fig. 1]. The MER of GP is not known, although clast production is interpreted to have been through a rapid "effusive" manner with subsequent fragmentation in the water column [Carey et al. 2018; Manga et al. 2018a]. The ALB deposit is a much smaller multilobate unit of vesicular ash, lapilli, and blocks [Fig. 2g-i], lobes that extend up to two $\mathrm{km}$ from the main vent (upon which Dome OP sits) [Fig. 1]. The ALB unit has an eruptive volume of $\sim 0.01 \mathrm{~km}^{3}$ and areal extent of $\sim 3.5-4.0 \mathrm{~km}^{2}$; eruptive duration, MER, and mechanism of formation and deposition are unknown [Carey et al. 2018]. Based on stratigraphic observations (ALB overlying GP) and deposit geometry, Carey et al. (2018) hypothesized that ALB was the result of deposition from density currents following the deposition of the GP clasts. The geochemistry of ALB also matches that of RP and GP [Carey et al. 2018]; this study will present the first textural data for the pumice-rich ALB unit. The $O M$ difference in eruptive volume between the raft $\left(\sim 1.2 \mathrm{~km}^{3}\right)$ and combined seafloor pumice units $\left(>0.11 \mathrm{~km}^{3}\right)$ highlights the importance of combining raft and seafloor observations and measurements when quantifying and classifying submarine eruptions by MER and/or total eruptive volume.

Despite the different depositional fate, the seafloor and raft pumices have similar bulk porosities and macrotextural characteristics [Carey et al. 2018]. This raises the question what are the measurable properties/characteristics that separated rafted pumice from pumice deposited on the seafloor? Manga et al. (2018a) found through experiments that raft pumices trap more gas than seafloor pumice through capillary processes, but the physical characteristics and controls that lead to gas trapping were unknown. In this study, we identify the microtextural and vesicle connectivity differences between raft (RP) and seafloor pumice (GP \& ALB). We here illustrate how these textural differences can lead to major differences in pumice fate (sinking vs. floating) and later discuss the mechanisms and physical controls through which internal microtextures can affect pumice dispersal. 


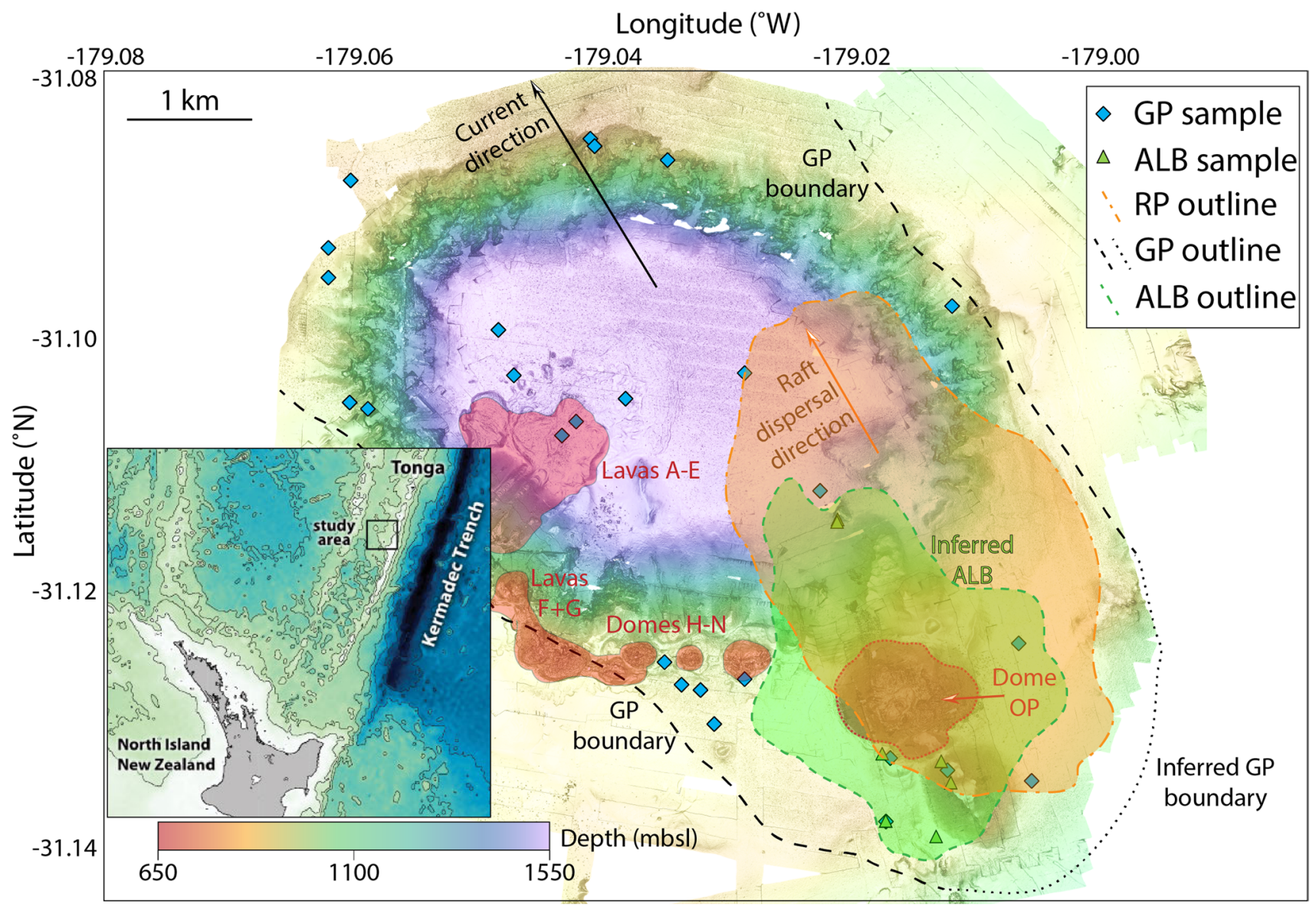

Fig. 1 Sample locations from the MESH 2015 expedition and inferred pumice unit outlines for the 2012 Havre eruption; AUV bathymetry from Carey et al. (2018). Inset shows the Havre caldera location on the Kermadec Ridge [Carey et al. 2014]. RP was sampled at distant shorelines (Fiji) but originated and dispersed from the vent beneath Dome OP; outlined here (orange dashed area) as the pumice

\section{Controls on pumice buoyancy in water}

Ultimately, a pumice clast (including its fluid-filled pore space) must be denser than the surrounding medium, i.e., water (density $\sim 1000 \mathrm{~kg} \mathrm{~m}^{-3}$ for freshwater or $\sim 1027 \mathrm{~kg} \mathrm{~m}^{-3}$ for seawater), to be able to sink; the ingestion of seawater into pumice (and loss of gas from pore space) is the primary cause of sinking [Cashman and Fiske 1991; Allen et al. 2008; Fauria et al. 2017; Fauria and Manga 2018]. Pumice clasts are initially filled with magmatic volatiles (primarily water vapor). Air can replace the water vapor during subaerial eruptions. Air $\left(\sim 2.0 \mathrm{~kg} \mathrm{~m}^{-3}\right)$ may also be entrained into pumice clasts when clasts reach the ocean surface from submarine eruptions, although this process has not been quantitatively demonstrated. The presence of air within clasts is important because the trapping and retention of non-condensable gas causes flotation [Fauria et al. 2017]. Non-condensed raft at the ocean's surface based on MODIS satellite images from July 19, 2012 [Carey et al. 2018]). The GP outline is identified by a transition of smooth to rough (GP-hosting) seafloor. The inferred ALB outline is defined by a transition from rough to smooth (ALB-hosting) seafloor. Effusive 2012 deposits (lavas A through N) are highlighted in red

$\mathrm{CO}_{2}$ bubbles from magmatic degassing $\left(\sim 2.0 \mathrm{~kg} \mathrm{~m}^{-3}\right.$ at ambient pressure and temperature) may also play a role in flotation, but typically water vapor is the dominant magmatic volatile in silicic melts and present as vapor or condensed liquid in bubbles/vesicles by surface emergence.

The total porosity, $\varnothing_{t}$ (pore space including vesicles, cracks, and voids), of pumice is given as the combined volume of connected porosity, $\varnothing_{c}$, and isolated porosity, $\varnothing_{i}$ [Eq. 1]:

$\varnothing_{t}=\varnothing_{i}+\varnothing_{c}$

where vesicle "connectivity," $c$, is given as the ratio of connected to total porosity [Eq. 2]:

$c=\frac{\varnothing_{c}}{\varnothing_{t}}$ 

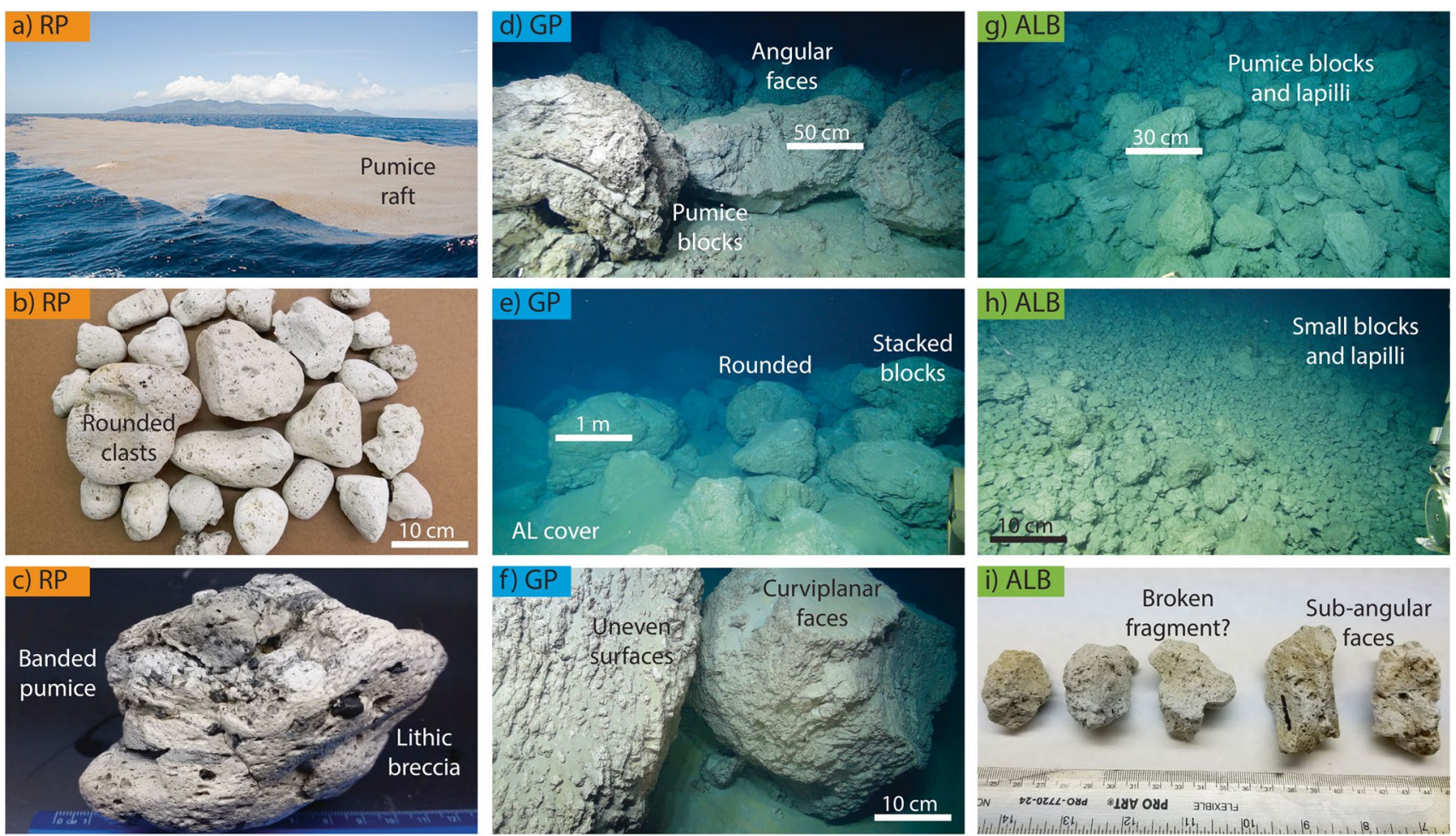

Fig. 2 Whole clast textures of rafted and seafloor pumices from the 2012 Havre eruption. a The coherent pumice raft observed 8 weeks after the eruption from the HMS Canterbury; $\mathbf{b}$ raft pumice washed ashore in Fiji in summer 2013; c lithic breccia and banding in raft pumice collected in New South Wales, Australia; d, e, f meter-scale

Isolated porosity is defined as any pore space that is not connected to the exterior of a clast; this may be singular isolated vesicles or connected vesicles with no clast exterior connection. Generally, vesicle connectivity in pumice is found to increase with total porosity and is close to complete $(c=1)$ above a percolation threshold at porosities $>70 \%$, although this is variable across different deposits and compositions [Rust and Cashman 2004; Colombier et al. 2017; Cassidy et al. 2018; Bernard and Bouvet de Maisonneuve 2020].

The movement of pumice clasts on the ocean surface by wave action and surface currents permits the ingestion of air into pore space [Cashman and Fiske 1991; Jutzeler et al. 2020]. The subsequent ingestion of seawater into the connected porosity may cause this air to be trapped. Trapped gas within isolated or connected porosity may allow pumice to remain afloat for up to many years on the ocean surface [Bryan et al. 2012; Manga et al. 2018a]. Gas may be trapped in connected porosity by the process of capillary (gas) trapping, whereby fluids are trapped in pore space by another fluid phase and trapping is influenced by pore geometry [Wardlaw 1982; Fauria et al. 2017; Chao et al. 2019].

This study will demonstrate how vesicle connectivity is a fundamental control on how efficiently pumices can trap giant pumice blocks (GP); $\mathbf{g}$ and $\mathbf{h}$ vesicular blocks and lapilli from ALB - $\mathbf{h}$ is further from source; $\mathbf{i}$ lapilli-sized ALB clasts with subangular faces. Scales are added appropriately to the perspective location within the figure

gas and remain afloat. We conducted detailed analysis of pumice macrotextures (density and componentry), microtextures (vesicle number densities and volume distributions), and pore structure (permeability, vesicle connectivity, and vesicle throat diameters) to identify physical differences between the raft and seafloor pumice populations of the 2012 Havre eruption.

\section{Methodology}

Around 240 pumice raft clasts (RP) $2-20 \mathrm{~cm}$ in diameter were collected from the shores of Fiji and New South Wales, Australia, approximately 1 year after the eruption; major element geochemistry verified the clasts' origin [Carey et al. 2018]. The Mapping, Exploration, and Sampling at Havre (MESH) expedition in 2015 collected up to 100 clasts (8-32 $\mathrm{mm}$ in diameter) from the vent-proximal ALB unit at nine locations (six analyzed here) and $29 \mathrm{dm}$-sized fragments of giant pumice block exteriors using the remotely operated vehicle (ROV) Jason [Carey et al. 2018; Mitchell et al. 2019]. One whole giant pumice, named GP290 $(1.5 \times 1 \times 1 \mathrm{~m})$, was brought to the surface intact by the ROV Jason and studied in detail by Mitchell et al. (2019). 
This study utilizes existing data from GP290; we note that GP290 represents a textural endmember within the giant pumice deposit because of the presence of $\mathrm{cm}$-thick gray bands throughout the clast [Mitchell et al. 2019].

All clasts and fragments were washed in an ultrasonicator, cleaned, and dried at $80^{\circ} \mathrm{C}$ for over $24 \mathrm{~h}$ before analysis. For each sample, we measured the density of all particles/ broken GP fragments that were $8-32 \mathrm{~mm}$ in diameter following Houghton and Wilson (1989); density measurements have $\pm 15 \mathrm{~kg} \mathrm{~m}^{-3}$ error. Vesicularity was determined using a whole rock density of $2380 \mathrm{~kg} \mathrm{~m}^{-3}$, as analytically determined by Mitchell et al. (2019) through helium pycnometry on 28 GP block fragments. Individual clasts were then assigned a macrotextural identity for componentry analysis, with classifications similar to those assigned by Mitchell et al. (2019) and Murch et al. (2019a). Clasts were classified as banded (presence of gray $\mathrm{cm}$ - and/or mm-sized bands in predominantly white pumice), tubular (texture dominated by elongate and/or "tube" vesicles oriented in a single direction), or uniform (texturally uniform white pumice with no significant gray banding or vesicle elongation). Clasts selected for 2D microtextural analysis were taken from the modal density category of each unit (RP and ALB) and then from the tail ends of each density distribution to cover the range of vesicularities observed within each unit. Microtextural data for GP and GP290 was taken from an extensive study of the giant pumice blocks by Mitchell et al. (2019); the fragments selected for GP microtextural analysis were taken only from the modal density category of the density distributions, as some ROV-sampled materials were limited, particularly at lower vesicularity.

To conduct 2D quantitative microtextural vesicle analysis, backscattered electron (BSE) images from 18 thin sections were acquired at $50 \times, 250 \times$, and either $500 \times$ or $750 \times$ magnification (depending on the apparent number of vesicles $<10 \mu \mathrm{m}$ in diameter) and as whole thin section scans. Vesicle sizes measured here were $2-4000 \mu \mathrm{m}$ in diameter. BSE images were acquired using a JEOL JXA-8500F microprobe analyzer at $15 \mathrm{keV}$ accelerating voltage with an $8 \mathrm{nA}$ beam current at the University of Hawai' $\mathrm{i}$ at Mānoa. BSE images were subsequently processed through the image processing software, FijiApp [Schindelin et al. 2012], where the area and number of vesicles and the number and size of minimum vesicle throat diameters $\left(D_{\mathrm{th}}\right)$ were determined for each image. In this study, we analyzed vesicles and throat diameters within thin sections from individual clasts: five RP, five ALB, five GP, and three GP290.

We calculated vesicle number densities corrected for vesicularity $\left(N_{\mathrm{Vm}}\right)$ and vesicle volume distributions (VVDs) following Sahagian and Proussevitch (1998) and the same image nesting structuring used by Mitchell et al. (2019); these calculations were performed on manually "decoalesced" vesicle images. The minimum vesicle throat diameter $\left(D_{\mathrm{th}}\right)$ is quantified here as the narrowest opening between the two connected vesicles. These narrowest openings also mark the same spot where vesicles were "decoalesced," to remain consistent with $N_{\mathrm{Vm}}$ and VVD analysis. $D_{\text {th }}$ analysis was done for eight $250 \times$ magnification BSE images from each of the 18 thin sections assessed for $N_{\mathrm{Vm}}$ and VVD analysis; almost 20,000 throat diameters were measured in total across all clasts. A $250 \times \mathrm{BSE}$ image resolution was $2670 \mathrm{pixe} / \mathrm{mm}$ such that we could resolve bubble walls down to $\sim 0.38 \mu \mathrm{m}$ thick. With a 2 pixel resolution, we set the minimum detection threshold of vesicle throats at $\sim 1 \mu \mathrm{m}$.

We used an AccuPyc II 1340 Gas Pycnometer at the University of Oregon to determine total porosity $\left(\varnothing_{t}\right)$ and isolated porosity $\left(\varnothing_{i}\right)$ of cylindrical cores and fragments of cmsized pumice clasts from RP, GP, and ALB to accompany existing data for RP and GP290 [Manga et al. 2018a]; these analyses were used to determine vesicle connectivity. All cylindrical cores were $2.2-2.8 \mathrm{~cm}$ in diameter and $\sim 3 \mathrm{~cm}$ in depth. A PMI CFP-34RUE8A-3-6 Capillary Flow Porometer at the University of Oregon was used to measure Darcian $\left(k_{1}\right)$ and inertial $\left(k_{2}\right)$ permeability of cores from RP to add to the existing permeability data for GP and GP290 [Mitchell et al. 2019]. This study combines existing data from the seafloor (GP) with new measurements from the Havre 2012 pumice raft (RP) and seafloor pumice unit, ALB. Further details on collection and processing of samples, microtextural methods, pycnometry, and capillary flow porometry can be found in Supplements 1-3.

\section{Results}

\section{Macrotextures: density and componentry}

The macrotextures of RP, GP, GP290, and ALB clasts are all very similar [Figs. 2 and 3], as shown similarly by Carey et al. (2018) for preliminary raft and GP data. RP, GP, and ALB exhibit similar ranges in vesicularity with modal vesicularities between 70 and $85 \%$, with mean and medians of $72-77 \%$ and $75-79 \%$, respectively [Fig. 3a]. RP has a lower vesicularity limit of 57\% (consistent with density equivalent to seawater $-1027 \mathrm{~kg} \mathrm{~m}^{-3}$ ); ALB and GP seldom reach below this (48\% at the very lowest). All units have clasts with up to $~ 92 \%$ vesicularity and share similar clast componentry, as most clasts exhibit uniform macrotextures [Fig. 3]. Componentry and density is discussed further in Supplement 4.

GP blocks have a variety of morphologies and can exhibit very blocky, angular, and irregular exteriors [Fig. 2d-f] 


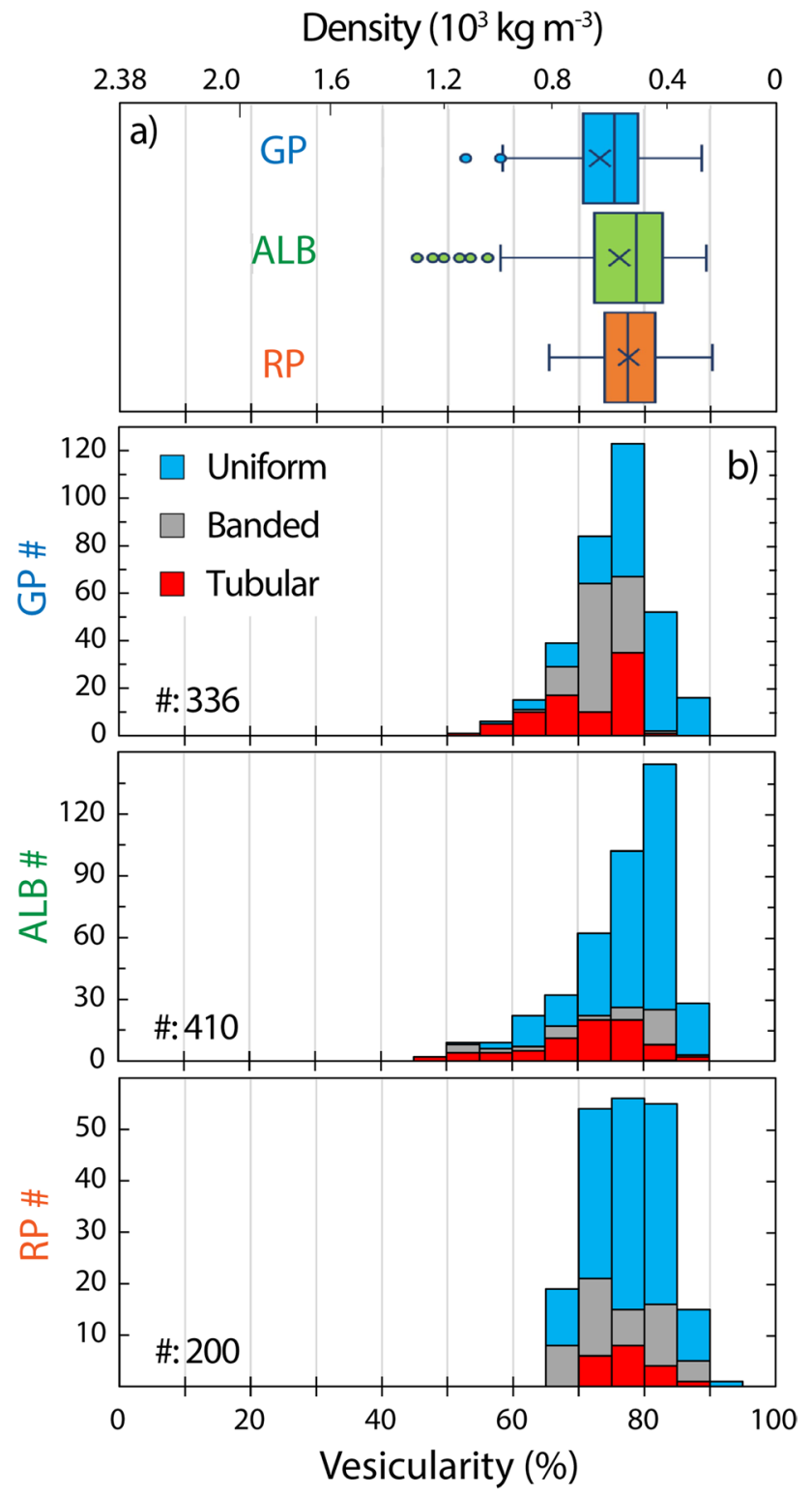

Fig. 3 a Box and whisker plots of density and corresponding vesicularity $\left(\mathrm{DRE}=2380 \mathrm{~kg} \mathrm{~m}^{-3}\right)$ for all $8-32 \mathrm{~mm}$ clasts/fragments from each 2012 unit sampled. Each plot gives the mean $(\times)$, median (-), interquartile range (box), 5-95th percentiles (whiskers) and outliers $\left({ }^{\circ}\right)$. b Textural componentry of all $8-32 \mathrm{~mm}$ clasts/fragments analyzed from each unit. \# denotes the number of clasts/fragments analyzed

[Mitchell et al. 2019], whereas ALB clasts were mostly sub-angular to sub-rounded with a notable absence of well-rounded clasts, attributed by Carey et al. (2018) to pervasive clast break up during transport [Fig. $2 \mathrm{~g}-\mathrm{i}$ ] . RP clasts $(2-20 \mathrm{~cm})$ were usually sub- to well-rounded, presumably due to heavy abrasion and comminution from clast-clast-wave interactions in the raft. Overall, there is no significant macrotextural variation observable between the raft and seafloor units, aside from clast size and shape, which are attributed to secondary fragmentation mechanisms.
Microtextures: vesicle number densities and volume distributions

There is, however, microtextural variability between, and within, the RP, GP, and ALB deposits [Fig. 4; Supplement 5]; a summary of all vesicle microtextural data can be found in Table 1. RP clasts have higher vesicle number densities $\left(N_{\mathrm{Vm}}, 9.7 \times 10^{8}\right.$ to $\left.1.5 \times 10^{9} \mathrm{~cm}^{-3}\right)$ than all seafloor GP $(1.9$ $\times 10^{8}$ to $6.0 \times 10^{8} \mathrm{~cm}^{-3}$ including GP290) or ALB $(3.1 \times$ $10^{8}$ to $7.8 \times 10^{8} \mathrm{~cm}^{-3}$ ) clasts [Fig. 5a]. The range of $N_{\mathrm{Vm}}$ values from Havre $\left(10^{8}-10^{9} \mathrm{~cm}^{-3}\right)$ sits within $N_{\mathrm{Vm}}$ data from pumice of other submarine silicic centers along the Kermadec Arc and the shallow subaqueous 1.8 ka Taupo eruption [Fig. 5] [Houghton et al. 2010; Rotella et al. 2015]. Havre 2012 raft $N_{\mathrm{Vm}}$ values from Rotella et al. (2015) are very similar to our determined values, which are reassuring [Fig. 5a]. The higher $N_{\mathrm{Vm}}$ values in Havre raft pumice are more apparent in lower vesicularity BSE images from smaller vesicle sizes [Fig. 4d]. Raft pumice vesicles are mostly circular and lack preferred orientation, and most coalesced vesicles have narrower bubble throats than vesicles in seafloor samples (GP and ALB). GP fragments have larger vesicles on average and fewer fully circular vesicles; vesicles in ALB clasts are most similar to vesicles in GP fragments [Fig. 4].

All units have similar vesicle number distributions for vesicle diameters between 30 and $1000 \mu \mathrm{m}$ [Fig. 5b, Supplement 6]. Below $30 \mu \mathrm{m}$, RP deviates from the seafloor pumice where there are as many as double the number of vesicles $\left(N_{\mathrm{V}}\right)<10 \mu \mathrm{m}$, and $<3 \mu \mathrm{m}$, than the seafloor pumices [Fig. $5 \mathrm{c}$ ]. Higher $N_{\mathrm{Vm}}$ in RP clasts are attributed to this greater number and volume of vesicles $<30 \mu \mathrm{m}$ in diameter (22-30 vol.\% in RP vs 10-25\% in GP and ALB) [Fig. 5d and Table 1]. The greatest statistical difference in vesicle volume between seafloor and raft occurs at vesicles of 15-50 $\mu \mathrm{m}$ [Supplement 7], suggesting that vesicles of this size may play an important role in whether pumice float or sink.

\section{Permeability and vesicle connectivity}

Darcian permeability $\left(k_{l}\right)$ spans 3.5 orders of magnitude (5 $\times 10^{-13}-9 \times 10^{-10} \mathrm{~m}^{2}$ ) throughout seafloor pumice, between and within individual clasts [Mitchell et al. 2019], whereas raft pumice have a narrower but overlapping lower range from $7 \times 10^{-13}-9 \times 10^{-12} \mathrm{~m}^{2}$ [Fig. 6a,b]. There is no correlation of $k_{l}$ with total porosity $\left(\varnothing_{t}\right)$ or connected porosity $\left(\varnothing_{c}\right)$ within GP or RP. GP290 shows a similar $k_{l}$ range to RP at lower $\varnothing_{t}$. Similarly, inertial permeability $\left(k_{2}\right)$ values are narrower and smaller in RP $\left(2 \times 10^{-9}-7 \times 10^{-8} \mathrm{~m}\right)$, whereas GP $k_{2}$ values are broader and can be higher $\left(2 \times 10^{-9}-2 \times\right.$ $10^{-6} \mathrm{~m}$ ) except for GP290 with lower $k_{2}$ values [Supplement 8]. Overall, there is no apparent sharp separation between raft and seafloor permeability, but GP clasts may have much higher permeability. In any case, Fauria and Manga (2018) 
Fig. 4 Binary BSE images for each of the pumice units taken at $50 \times(\mathrm{a}, \mathrm{e}, \mathrm{i})$ and $250 \times$ (rest) magnification; scale bar $=1 \mathrm{~mm}$ in $50 \times$ images and $10 \mu \mathrm{m}$ in $250 \times$ images. Vesicles are in black, crystals in gray, and glass in white. Vesicles in $250 \times$ images are decoalesced for number density $\left(N_{\mathrm{Vm}}\right)$ analysis. In each image are reported vesicularity (\%) and whole clast-corrected $N_{\mathrm{Vm}}$ in $\mathrm{cm}^{-3}$
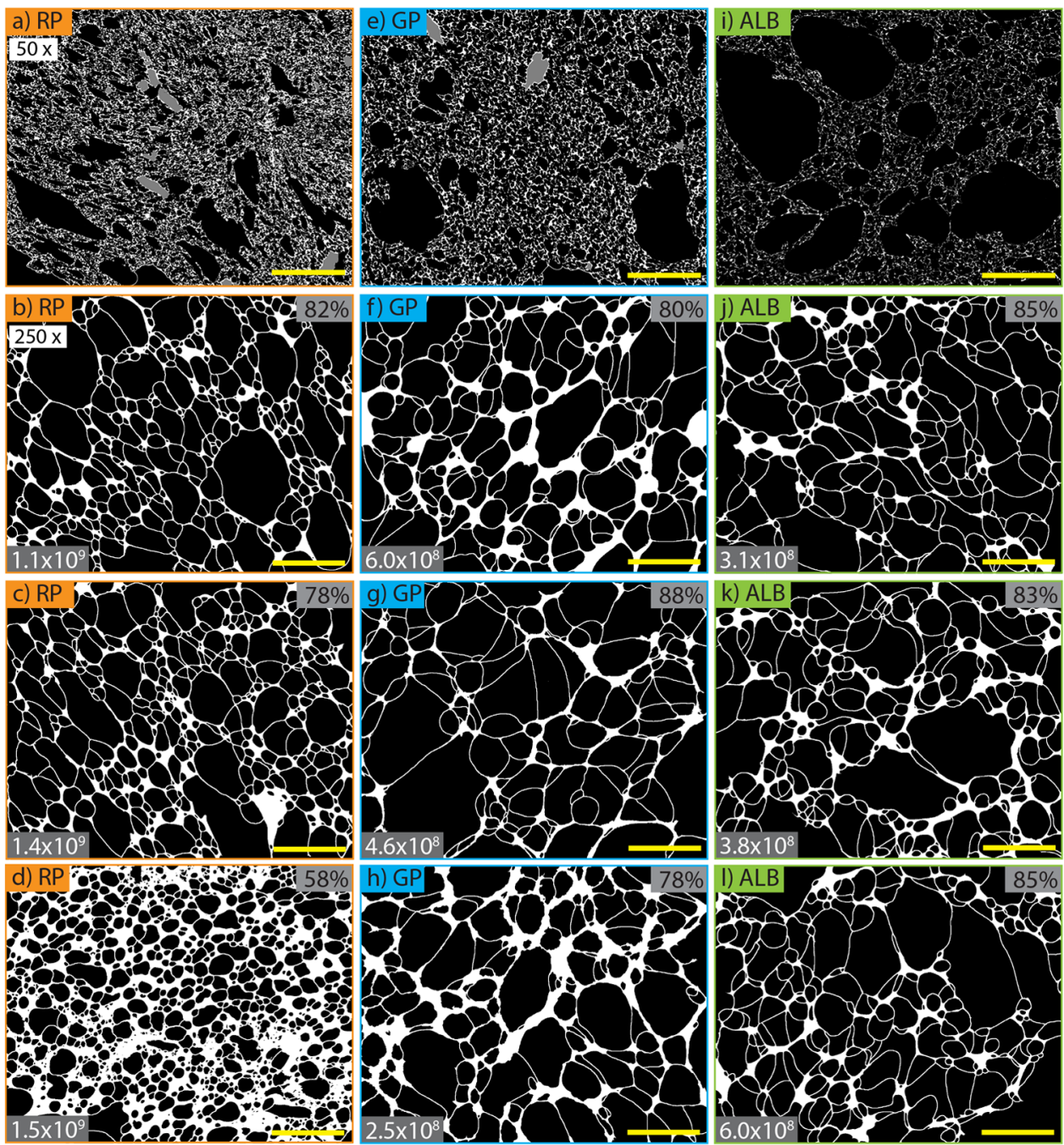

show that seawater ingestion during pyroclast cooling is not a permeability-limited process.

He pycnometry, however, reveals a significant difference between values of vesicle connectivity $(c)$ in floating clasts (RP) versus clasts that sunk to the seafloor (ALB and GP) [Fig. 6c]. RP clasts have lower vesicle connectivity (i.e., higher isolated porosity, $\varnothing_{i}$ ) than GP and ALB fragments despite showing similar total porosities $\left(\varnothing_{t}=60-92 \%\right)$. RP clasts have connectivity, $c$, ranging between 0.35 and 0.95, whereas for GP and ALB clasts, $c$ ranges from 0.92 to $1.0(1.0=100 \%$ vesicle connectivity $)$. The low connectivity $(c<0.7)$ of some raft pumice is very surprising for such highly vesicular pumice, because subaerial pumice above $70 \%$ porosity usually exhibit very high — if not full - connectivity in 3D [Degruyter et al. 2012; Colombier et al. 2017]. The heavily banded GP290 has a narrower $\varnothing_{t}$ range (74-82\%), but vesicles are near fully connected $(c=0.97-1.0)$ and distinct from other uniform GP, as shown by Mitchell et al. (2019). ALB clasts are more similar to GP, mostly being, fully connected $(c \sim 1.0)$ at $\varnothing_{t}>85 \%$ [Fig. 6d].
In summary, RP, GP + ALB, and GP290 show three distinct connectivity-porosity relationships [Fig. 6c, d].

\section{The connectivity threshold for clast floating or sinking}

When vesicles in a pumice clast are entirely connected $(c=1)$ and the connected pore space is fully saturated with liquid water, the clast will sink. However, if clasts have isolated porosity $(c<1)$, they may be able to float even when their connected pore space is filled with liquid water [Fig. 6e]. We calculated the maximum connectivity $\left(c_{\text {ths }}\right)$ that enables flotation of clasts that have connected porosity saturated with a water volume fraction of liquid $(s)$ as

$c_{t h s}=\frac{\rho_{\text {clast }}-\rho_{r}+\left(\rho_{r}-\rho_{g}\right) \varnothing_{t}}{\left(\rho_{s w}-\rho_{g}\right) s \varnothing_{t}}=\frac{2379 \varnothing_{t}-1353}{1026 s \varnothing_{t}}$

This was derived from a mass balance relationship and the connectivity equation [Eq. 2]: 


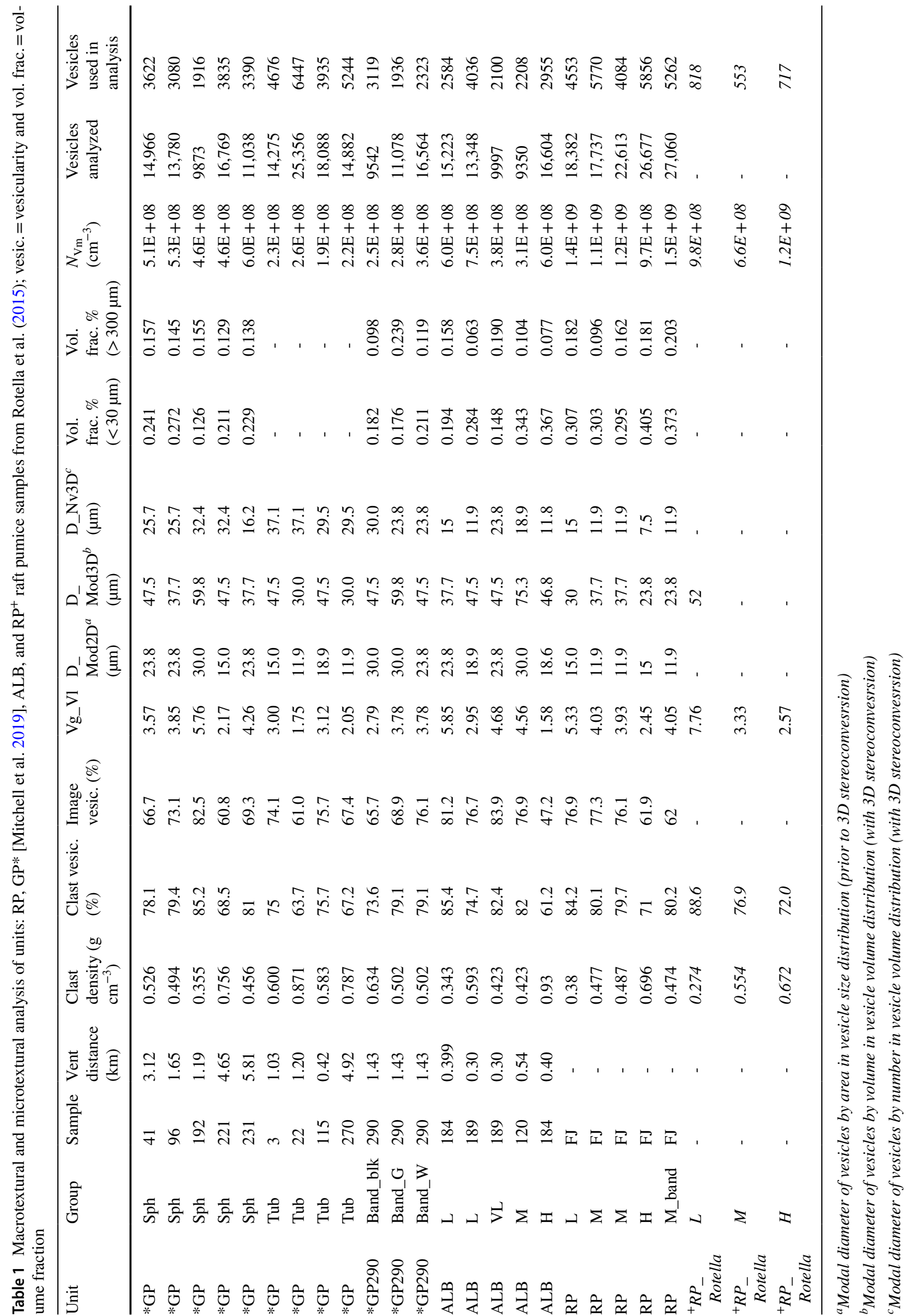



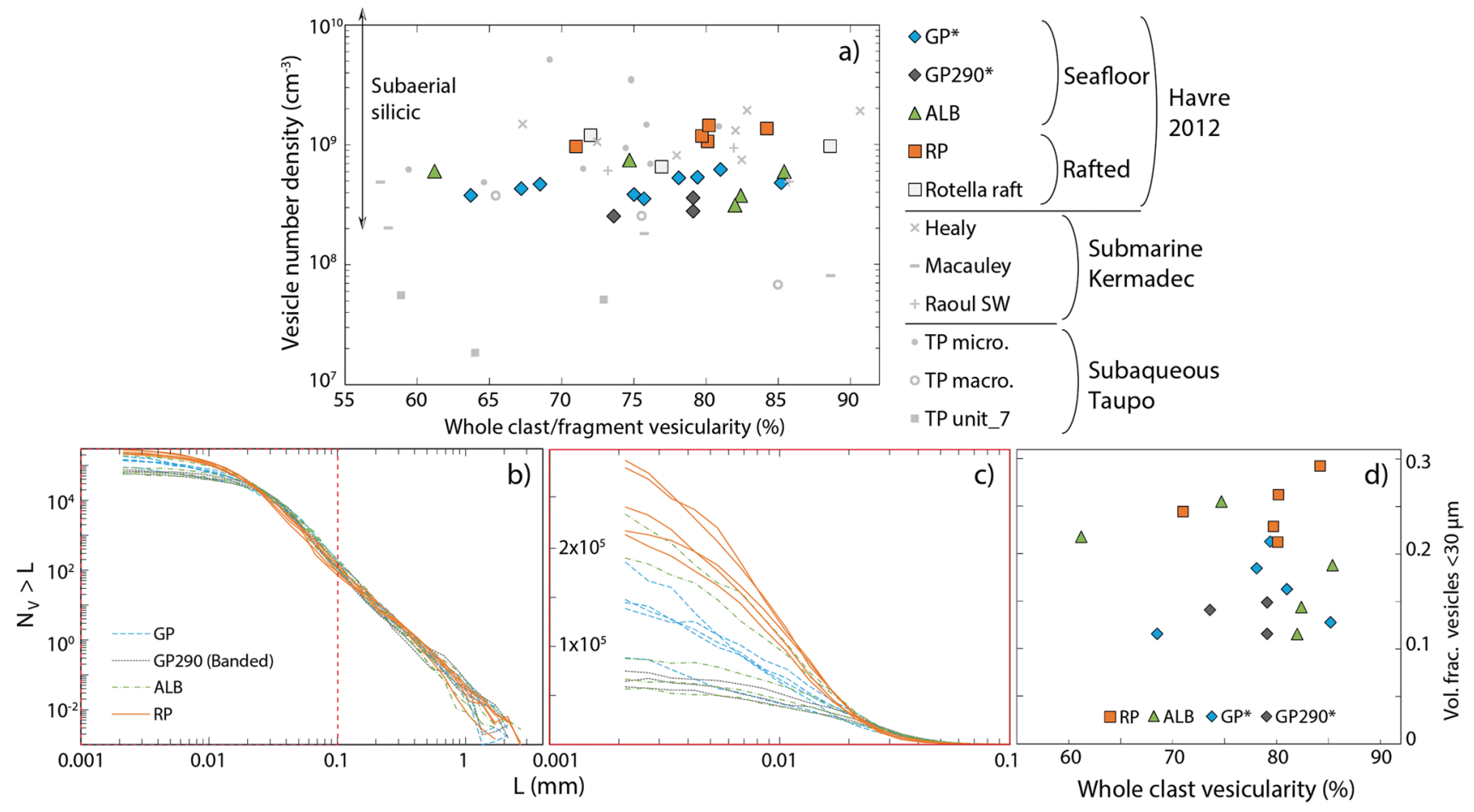

Fig. 5 a Corrected vesicle number density $\left(N_{\mathrm{Vm}}\right)$ for Havre 2012 pumice and pumice from other silicic eruptions vs. whole clast vesicularity (\%); $\mathbf{b}$ the number of vesicles greater than a given diameter (L) between 2 and $3000 \mu \mathrm{m}$ for each sample analyzed - c expands the differences between samples at the smallest vesicle sizes $(<100 \mu \mathrm{m}) ; \mathbf{d}$ the $\%$ volume fraction of vesicles $<30 \mu \mathrm{m}$ in diameter

$\rho_{\text {clast }}=\left(1-\varnothing_{t}\right) \rho_{r}+\varnothing_{i} \rho_{g}+s \varnothing_{c} \rho_{s w}+(1-s) \varnothing_{c} \rho_{g}$

where $\varnothing_{t}$ is the total porosity (fraction), $\varnothing_{i}$ is the isolated porosity, $\varnothing_{c}$ is the connected porosity, $s$ is the volume fraction of connected pore space filled with seawater, and $\rho_{\text {clast }}$, $\rho_{r}, \rho_{g}$, and $\rho_{s w}$ are the densities of the whole clast, bulk rock, trapped gas, and seawater, respectively. For our calculations and the derivation of Eq. 3, we assume $\rho_{s w}=1027 \mathrm{~kg} \mathrm{~m}^{-3}$ [Millero and Huang 2009], $\rho_{r}=2380 \mathrm{~kg} \mathrm{~m}^{-3}$ [Mitchell et al. 2019], and $\rho_{g}=1 \mathrm{~kg} \mathrm{~m}^{-3}$ (ambient air). The line in Fig. 6c illustrates how the flotation threshold, $c_{t h s}$, depends on clast porosity and $s$ (examples at $s=0.86$ and 1 ). For example, a clast with $90 \%$ porosity and a solid rock density of $2380 \mathrm{~kg} /$ $\mathrm{m}^{3}$ is always able to float if less than $85 \%$ of its pore space is fully connected, assuming $s=1$.

Lower porosity $\left(\varnothing_{t}<85 \%\right)$ RP clasts of low connectivity sit below the threshold, i.e., they will float depending solely on isolated porosity [Fig. 6d]. However, RP clasts with high connectivity $(c>0.8)$ at higher $\varnothing_{t}$ require greater trapped gas content to be able to float. A threshold where $s=0.86$ ( $>14 \%$ of connected porosity volume contains trapped vapor) is the best fit to separate all raft from seafloor pumice; however, $s$ will vary for individual clasts [Fig. 6] [Fauria et al. 2017]. Values of $s<1$ require that some gas remains trapped within for each sample.*GP and GP290 data acquired from Mitchell et al. (2019); ${ }^{+}$Rotella raft and submarine Kermadec data from Rotella et al. (2015); and subaerial and Taupō $1.8 \mathrm{ka}$ data from Houghton et al. (2010) - Taupō Unit 2 (micro- and macro-vesicular) and Unit 7 pumice blocks

the connected porosity, as experimentally demonstrated by Fauria et al. (2017), where ingested water prevented the escape of gas in some vesicles [Fig. 6e]. Our calculations also demonstrate that, at $c=1.0$, some pumice may be able to float without any isolated porosity, so long as $s$ values are sufficiently low, and the connected porosity traps enough gas. Our microtextural results raise the possibility that subtle changes in vesicle connectivity, as well as in the efficiency of gas trapping within connected porosity, may change the fate of pumice transportation and deposition during submarine eruptions.

\section{Vesicle throat diameters}

Vesicle throats (or "pore" throats) are the narrowest opening between two connected or "coalesced" vesicles [Fig. 7]. Pore throat size distributions are rarely reported in studies of volcanic products but are important to consider for assessing microscale permeability and fluid and gas flow within vesicle networks, in this case, gas trapping. We make these measurements because the pore-scale processes that impact water ingestion are not fully understood. These measurements attempt to link measured vesicle scale properties 


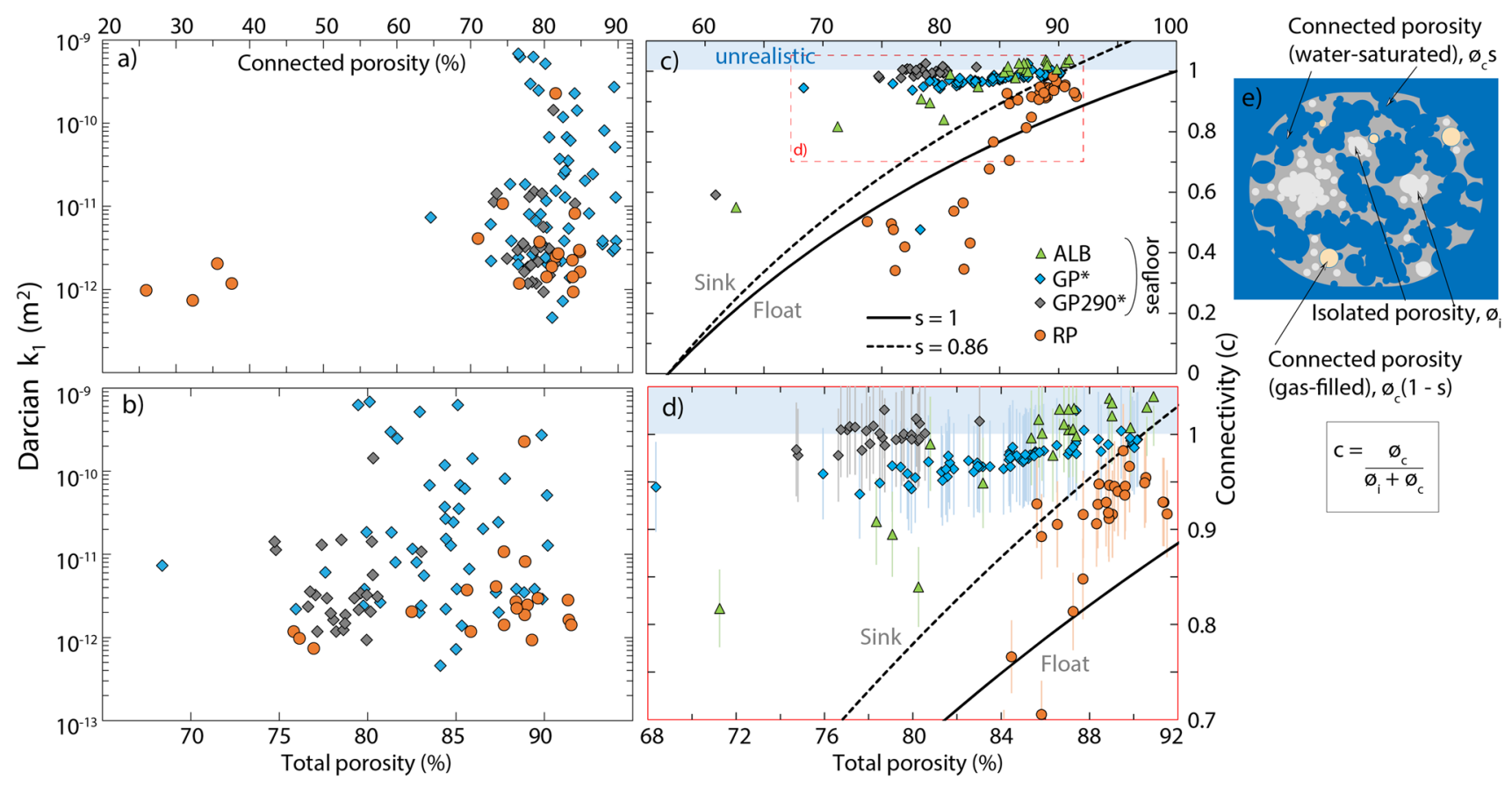

Fig. 6 Darcian permeability $\left(k_{l}\right)$ of cm-sized cores from raft and seafloor (GP) pumices vs. a connected porosity and b total porosity; $\mathbf{c}$ total porosity vs. vesicle connectivity of cores and fragments from $\mathrm{RP}, \mathrm{GP}$, and ALB; $\mathbf{d}$ is an inset of data from $\mathbf{c} ; \mathbf{e}$ illustrates a pumice clast with water-saturated connected porosity (blue), vapor-filled isolated porosity (white), and some gas trapping in connected porosity (yellow). *GP and some RP data acquired from Mitchell et al. (2019) and Manga et al. (2018a). Analytical error is given by error bars. Connectivity values $>1$ are attributable to analytical imprecision. $s$ lines represent a constant density of $1027 \mathrm{~kg} \mathrm{~m}^{-3}$ - the buoyancy threshold in seawater, where $s=$ fraction of connected porosity saturated by liquid seawater as shown in $c$ a)

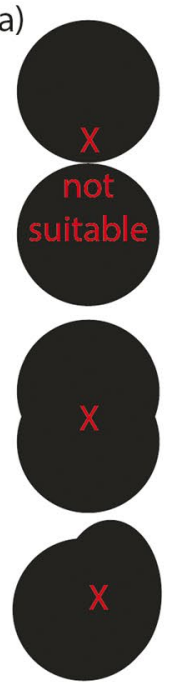

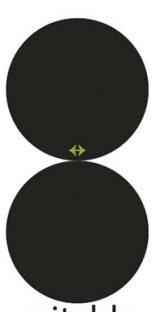

suitable

8X

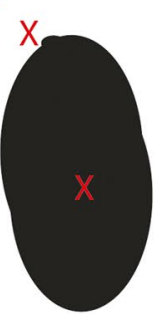

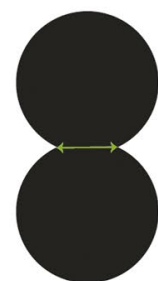

suitable

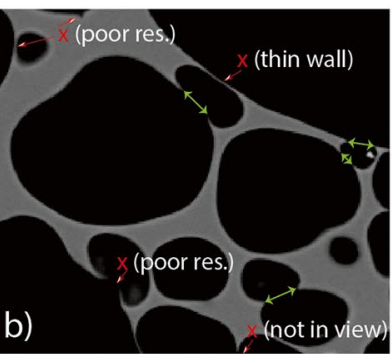

c)
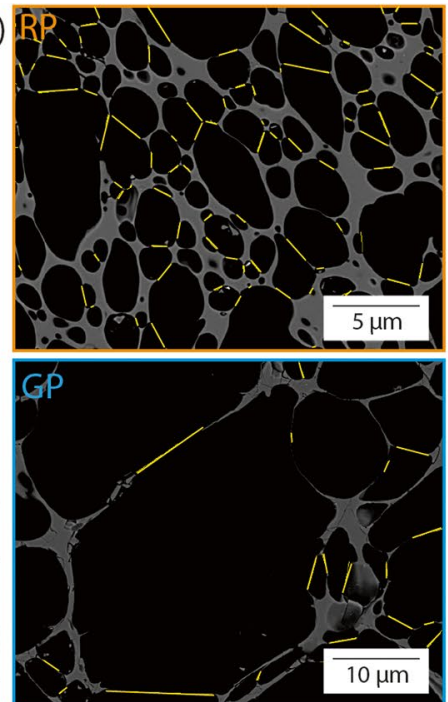

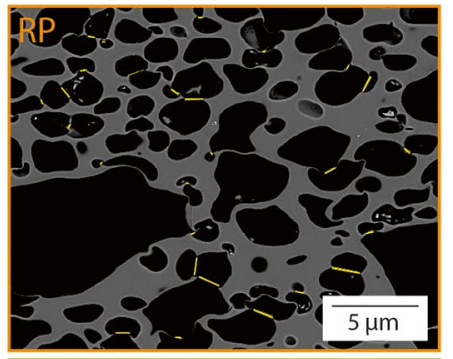

ALB

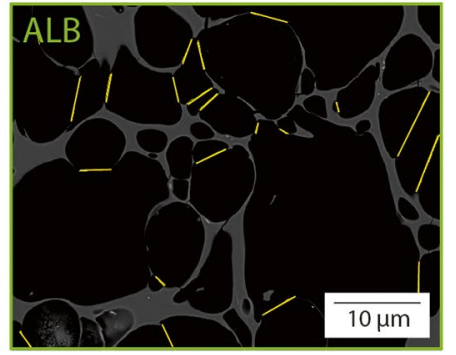

Fig. 7 a Choosing the suitability of vesicle throat measurements: only selecting where remnants (septa) of old bubble wall are clearly visible. $\mathrm{X}$ denotes where throat selections are not suitable; $\mathbf{b}$ example selection within a zoomed in BSE image of pumice (vesicle in black and glass in gray) - throats were not measured where there was poor image resolution, incomplete (not in view) throats, or where there were very thin walls; c examples of $250 \times$ (upper images) and $500 \times$ (lower images) BSE images with measured throats drawn as yellow lines 
[Figs. 5 and 6] with processes of gas trapping at the continuum scale.

Here, we manually measure pore throat sizes in 2D from the BSE images used previously for vesicle number analyses [Fig. 7c]. In BSE images, vesicle throats were clearly distinguished from more-rounded, vesicle edges by the presence of "tips" or "septa" indicating the breach of a thin bubble wall as two bubbles had connected through coalescence [Fig. 7a, b]. For each BSE image, we determined the number of throats (\#) and the average vesicle throat diameter $\left(D_{\mathrm{th}}\right)$. These values were also normalized by the area of glass + crystals in each BSE image $\left(A_{\text {gls }}\right)$. We combined these measurements with the measurements of vesicle diameters $\left(D_{\text {ves }}\right)$ within the same BSE images (at $250 \times$ magnification).

Figure 8 and Table 2 summarize average throat diameters $\left(D_{\mathrm{th}}\right)$ for all raft and seafloor pumice samples from Havre 2012; GP, GP290, and ALB all show very similar values and trends, so we will refer to these mostly as the "seafloor clasts." Raft pumices have average throat diameters of 5-10 $\mu \mathrm{m}$ across all image vesicularities (61-87\%), whereas seafloor pumice have average throat diameters of 9-20 $\mu \mathrm{m}$ across all vesicularity range [Fig. 8a]. Average throat diameter and normalized average throat diameter increase with vesicularity [Fig. 8a, c].

Measurements of the number (\#) of pore throats per image (or pore throat density) also reveal differences between rafted and seafloor clasts [Fig. 8b, d]. At vesicularities $>80 \%$, raft pumices have up to 300 throats/image, and seafloor clasts have $<200$ throats/image - most at 50-150 throats/image. At lower vesicularity $(<80 \%)$, raft pumices have a comparable pore throat density to seafloor pumice (80-170/image vs. 50-150/image, respectively) [Fig. 8b]. When normalized by glass + crystal area, throat density increases with vesicularity [Fig. 8d]. To summarize, high vesicularity $(>80 \%)$ raft pumices have a larger number of small pore throats compared to seafloor clasts of the same total vesicularity.

Prior measurements of average vesicle diameter $\left(D_{\text {ves }}\right)$ also show differences between seafloor and rafted pumice clasts [Fig. 8e, f and Table 1]. Seafloor clasts generally have larger average vesicle diameters compared to the rafted clasts. We find a positive correlation between average throat diameter and average vesicle diameter for raft and
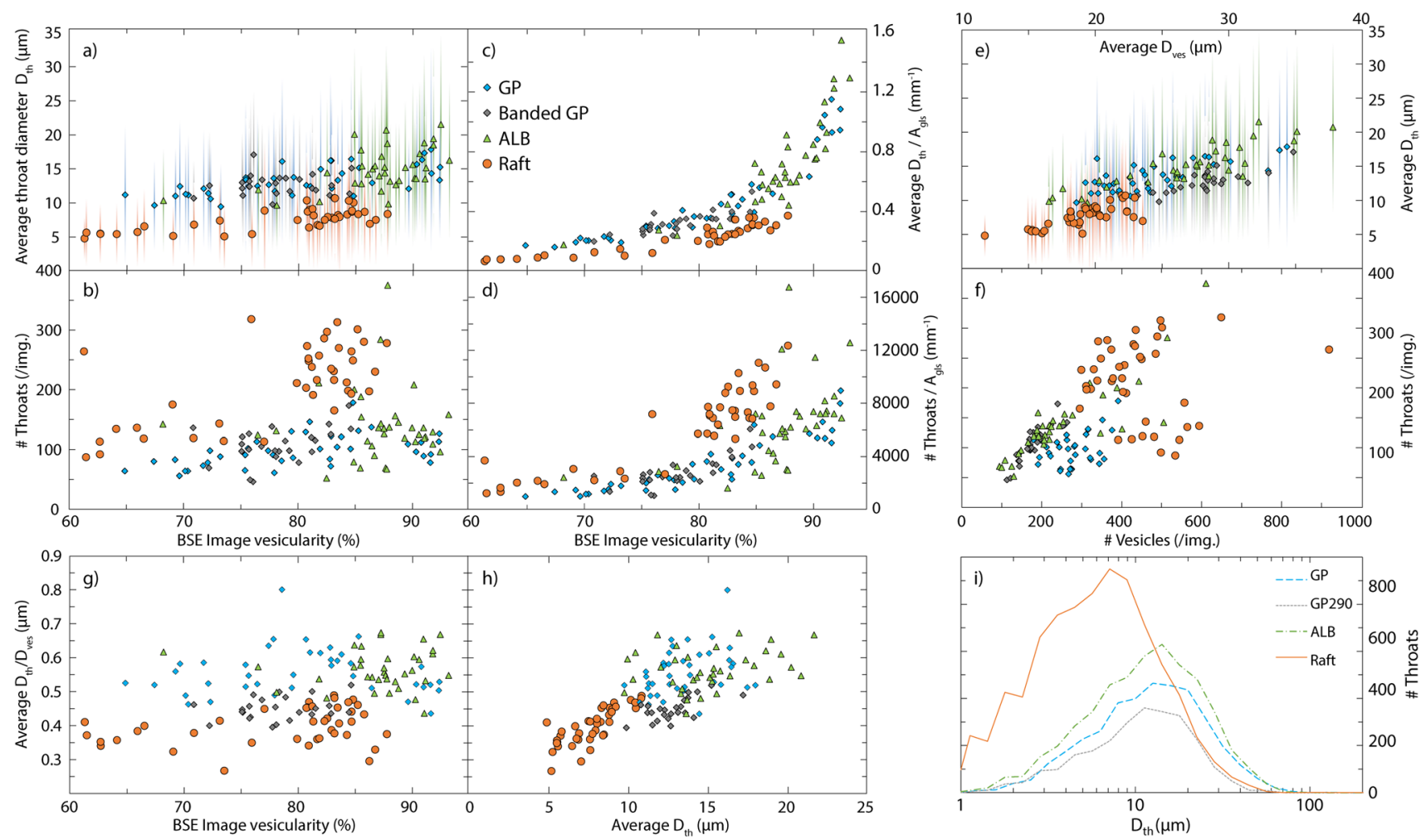

Fig. 8 Results of vesicle throat diameter $\left(D_{\text {th }}\right)$ analysis from BSE images; a-d Plots show, per image, the average \pm 1 standard deviation error bar, number (\#) of throats, and sum of all throat diameters, all vs. $2 \mathrm{D}$ image vesicularity (\%). Plots $\mathbf{c}$ and $\mathbf{d}$ have measurements normalized to the area of glass + crystals within the BSE image $\left(A_{\mathrm{gls}}\right)$; e average throat diameter $\left(D_{\mathrm{th}}\right)$ vs. the average circular diameter $\left(D_{\mathrm{ves}}\right)$ and $\mathbf{f}$ number of measured vesicle throats vs. number of vesicles within the same image; $\mathbf{g}, \mathbf{h}$ the ratio of average throat and vesicle diameter vs. image vesicularity and average throat diameter $\left(D_{\mathrm{th}}\right)$ per BSE image; i number of vesicle throats for a given size bin $\left(D_{\mathrm{th}}\right)$ as a vesicle throat number distribution for each pumice unit (collated samples for each unit). Throat diameters are calculated from 1 to $200 \mu \mathrm{m}$ 


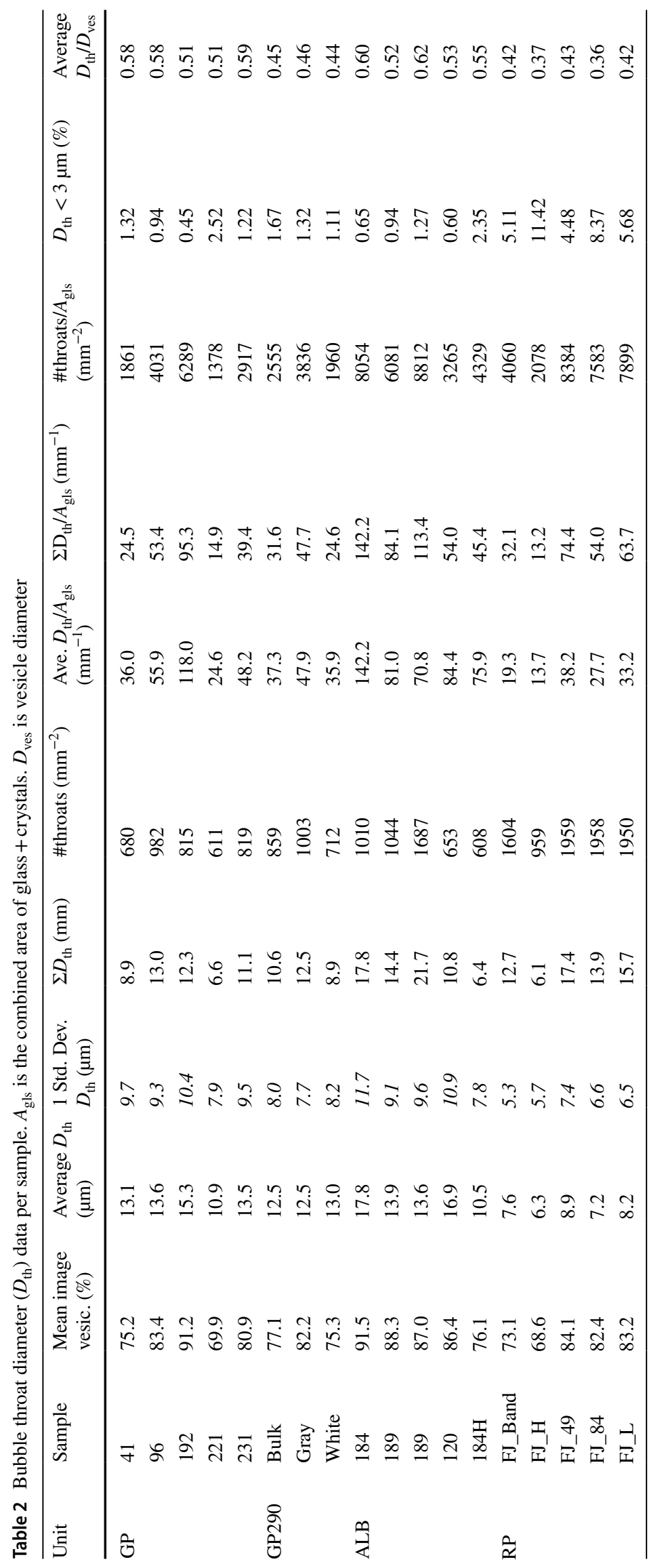


seafloor pumice [Fig. 8e]. Furthermore, raft pumices have consistently lower throat-to-vesicle diameter ratios $\left(D_{\text {th }} / D_{\text {ves }}\right)$ than seafloor pumice across all vesicularities, indicating that raft vesicles are more "poorly connected" $(0.25-0.47$ vs. 0.41-0.67) [Fig. 8g, h].

The vesicle throat size distributions measured over 1-200 $\mu \mathrm{m}$ between the different units clearly show how raft pumices are dominated by many small throats and few large throats [Fig. 8i]. Conversely, seafloor pumices have very few small throats with a common shift to larger average throat diameters by number [Fig. 8i]. Overall, our results highlight the importance of narrow vesicle throats in controlling the physical trapping of air and/or $\mathrm{CO}_{2}$ within the connected porosity of pumice clasts and, thus, floating vs. sinking.

\section{Discussion}

Our macrotextural analyses and previous work [Carey et al. 2018] show that raft and seafloor pumices have similar total porosities (vesicularity) and clast componentry [Fig. 3]. However, microtextural and porosity analysis identified that raft and seafloor pumice are distinguished by differences in vesicle number density [Fig. 5a], modal vesicle diameter [Fig. 5d and Table 1], vesicle connectivity and isolated porosity [Fig. 6c], and - with some overlap — permeability [Fig. 6a, b]. Additionally, pore throat analysis identified differences in the number and dimensions of vesicle throats [Fig. 8].

Here we discuss how these microtextural differences may partition pumice clasts into rafted and seafloor populations. Specifically, we discuss (1) how isolated porosity influences pumice flotation; (2) how capillary gas trapping works; (3) how the internal structure of pumice can impact capillary gas trapping; and (4) what implications our dataset and interpretations have for further studies. We begin by addressing the two microtextural subpopulations of raft clasts.

\section{Two populations of rafted pumice}

From connectivity and pore throat data, there are two distinct populations of raft pumice [Figs. $6 \mathrm{c}$ and $8 \mathrm{~b}, \mathrm{~d}$, and f]. The first population has lower total vesicularity $(<85 \%)$ and low vesicle connectivity (0.3-0.8), i.e., more isolated porosity. The second population has higher total porosity (>80-85\%) and much higher vesicle connectivity (0.8-1), i.e., very little isolated porosity. Below, we explain why isolated porosity and capillary gas trapping allow these two populations to float, respectively.

\section{Isolated porosity in pumice}

The high volume of isolated porosity (up to 50\%) allows the first subpopulation of (lower porosity) pumice to float due to isolated porosity alone [Fig. 6c]. High isolated porosity values are rare in pumice, although we note that most literature values of isolated porosity are from subaerial or very shallow subaqueous pumice deposits [Colombier et al. 2017 2021]. Although we have not constrained the processes that generated these vesicles, isolated porosity is usually attributed to the smallest bubbles, as larger bubbles usually relax, deform, and coalesce during bubble growth and magmatic strain [Shea et al. 2010]. This can be seen in some of our 2D imagery (e.g., Fig. 4) where the smallest vesicles appear isolated from surrounding, larger connected vesicles. Experimentally floated pumice clasts examined in Manga et al. (2018a b) also exhibited high volumes of isolated porosity. Nine of these pumice clasts are still floating as of the time of paper review - taking their total observed floatation time to over 5 years. This further highlights the influence of isolated porosity in pumice flotation.

Recent experimental work may suggest that proportions of isolated porosity are controlled by the ratio of dissolved volatile species, where higher $\mathrm{CO}_{2} / \mathrm{H}_{2} \mathrm{O}$ ratios increase isolated bubble nucleation [Pistone et al. 2021]. More targeted work is required to assess how differences in isolated porosity can be attributed to changes in degassing processes such as bubble nucleation in the shallow conduit (or above the vent for submarine eruptions).

The volume of isolated vesicles decreases rapidly at the percolation threshold - the onset of permeable outgassing through magma [Colombier et al. 20172020 2021; Giachetti et al. 2019]. In other eruptions, crystal-rich and/ or low viscosity magmas, early clast quenching significant bubble deformation, or the presence of connected void space and fractures may act to decrease the percolation threshold [Okumura et al. 2013; Lindoo et al. 2016 2017; de Graffenried et al. 2019; Colombier et al. 2021]. Polydisperse bubble populations with lower bubble number density are also more likely to produce magma with lower percolation thresholds [Giachetti et al. 2019; Vasseur et al. 2021]; this is observed conversely in experimental percolation studies, which commonly produce more monodisperse bubble populations in magma [Lindoo et al. 2016]. The percolation threshold may be increased in very viscous magmas due to viscous resistance to bubble coalescence [Colombier et al. 2017].

As the Havre magma is a crystal-poor, viscous rhyolite with relatively high bubble number density [Manga et al. 2018 a], a high percolation threshold ( $>70 \%$ porosity) is more probable. However, there is likely some additional bubble nucleation stage contributing to such high, isolated porosity values in the raft pumice, unseen in other vesicular rhyolites [Bouvet de Maisonneuve et al. 2009; Colombier 
et al. 2017; Giachetti et al. 2019]. This may be a textural signature unique to the conditions pertaining to deep submarine volcanism. From the results seen in this study, we conclude that a high proportion of isolated porosity will allow pumice to float unassisted by connected porosity gas trapping.

\section{Capillary gas trapping within connected porosity in pumice}

The high vesicularity (> 85\%) raft pumices (the second population referred to above) do not have sufficient isolated porosity to float. As a result, we infer that they require the trapping of gas within the connected porosity [Fig. 6c]. Capillary gas trapping is the processes through which noncondensable gas (i.e., air or $\mathrm{CO}_{2}$ ) is surrounded by liquid and rendered immobile within a porous material such as pumice; this is central to pumice flotation [Fauria et al. 2017]. Figure 9 illustrates how capillary trapping impacts final density and, thus, whether a pumice will float or sink. The schematic shows that lower vesicularity pumice of high connectivity (low isolated porosity) requires higher amounts of capillary trapping to float, utilizing either single bubbles or portions of a connected vesicle network [Fig. 9].

Capillary trapping has been well-studied in the engineering literature due to its significance for carbon sequestration and oil recovery. It has been shown that the overall amount of gas trapping is modulated by the pore structure, fluid flow rate, and wettability - the contact angle between the gas and the solid surface [Jerauld and Salter 1990; Blunt and Scher 1995; Valvatne and Blunt 2004; Krevor et al. 2015; Øren et al. 2019]. Below, we discuss processes that have been shown to control the amount of gas trapped by capillary processes in porous materials.

Capillary gas trapping occurs because surface tension forces $(\sigma)$ dominate at the pore-scale [Wardlaw 1982; Chao et al. 2019]. The capillary number (Ca) describes the ratio of viscous to surface tension forces as

Ca $=\frac{U_{b} \mu_{l}}{\sigma}=F^{\prime}\left(\frac{\text { viscous }}{\text { capillary }}\right)$

where $U_{b}=$ flow velocity, $\mu_{l}=$ viscosity of the liquid (seawater $=10^{-3} \mathrm{~Pa} \mathrm{~s}$ ), and $\sigma=$ gas-liquid surface tension $\left(\sim 0.07 \mathrm{~N} \mathrm{~m}^{-1}\right.$ for air and water). Flow velocity in a permeable submerged clast can be calculated according to Darcy's law as

$U_{b}=\frac{k \Delta \rho g}{\mu_{l} \varnothing_{c}}$

where $k=$ pore-scale permeability $\left(\mathrm{m}^{-2}\right), \varnothing_{c}=$ connected porosity fraction, and $\Delta \rho=$ density difference of gas and liquid $\left(\sim 1000 \mathrm{~kg} \mathrm{~m}^{-3}\right)$ [Hilfer and Øren 1996; Fauria et al. 2017].

In porous material such as pumice, when $\mathrm{Ca}$ is sufficiently low, and multiple fluid phases are present in the material (e.g., liquid water and air), capillary gas trapping can occur [Hu et al. 2020]; the critical capillary number that allows for gas trapping is lower for gas-water $\left(10^{-8}\right.$ to $<10^{-6}$ depending on flow rate and wettability) than oil-water systems $\left(\sim 10^{-5}\right)$ [Ding and Kantzas 2007; Guo et al. 2015]. Assuming permeable flow in pumice given in Eq. 6, we calculate Ca for all permeability data for raft and

\section{Pumice clast of porosity $=73 \%$, connectivity $=0.95$}

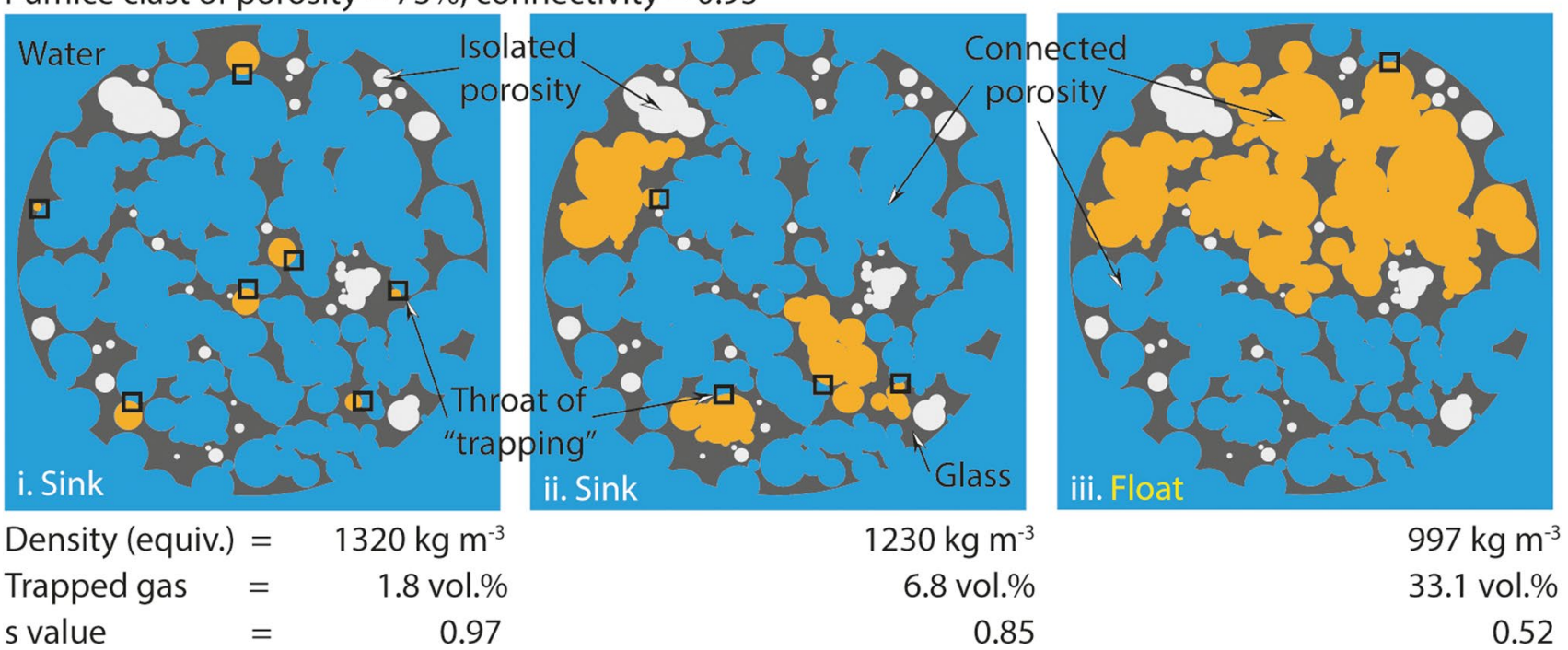

Fig. 9 Gas trapping within a 2D-schematic seawater-submerged pumice clast of $73 \%$ total porosity and $5 \%$ isolated porosity $(c=0.95)$ with three different amounts of gas trapped by narrow vesicle throats (indicated by black squares) and in isolated porosity. Bulk clast density was calculated using Eq. 4; glass, water, and gas density used are 2380,1027 , and $1.2 \mathrm{~kg} \mathrm{~m}^{-3}$, respectively 
seafloor pumice [Fig. 10]. We find that raft pumices consistently have $\mathrm{Ca}=10^{-7}-10^{-6}$ at higher isolated porosity fractions than seafloor pumice [Fig. 10b]; seafloor Ca values range from $10^{-7}$ to $10^{-3}$. Raft values are well in the realm of capillary gas trapping for a gas-liquid system [Ding and Kantzas 2007]. In Supplement 9, we calculate additional dimensionless parameters that further support the conclusion that capillary forces (surface tension) dominate inertia and viscous and gravitational forces and, thus, favor water ingestion of non-condensable, gas-filled pumice at vesicle sizes of 1-100 $\mu \mathrm{m}$. Experimental observations of gas trapping in pumice corroborate this calculation [Fauria et al. 2017; Manga et al. 2018a b].

It can be helpful to show why trapped gas bubbles do not always flow out of pumice by examining the pressure difference, or capillary pressure, across a gas-liquid interface (i.e., a bubble in water):

$\Delta P(r)=P_{\text {bubble }}-P_{\text {water }}=\frac{4 \sigma}{D_{\text {th }}} \cos \theta(r)$

where $\sigma$ is gas-liquid surface tension $\left(\sim 0.07 \mathrm{~N} \mathrm{~m}^{-1}\right.$ for air and water), $\theta$ is the wetting angle between the interface and the limiting wall (in this case, the vesicle edge), and $r$ is the lateral position across a given throat diameter [Fig. 11]. Often, $\theta$ is approximated to be 0 such that Eq. 7 can be simplified to $4 \sigma / \mathrm{D}$. For a gas bubble to pass through a pore throat or narrow constriction, the gas bubble must have a diameter less than or equal to the width of the opening $\left(D_{\text {ves }}<D_{\text {th }}\right.$ ) [Fig. 11a]. Although bubbles can deform (or break up) and pass through narrow constrictions [Dawson

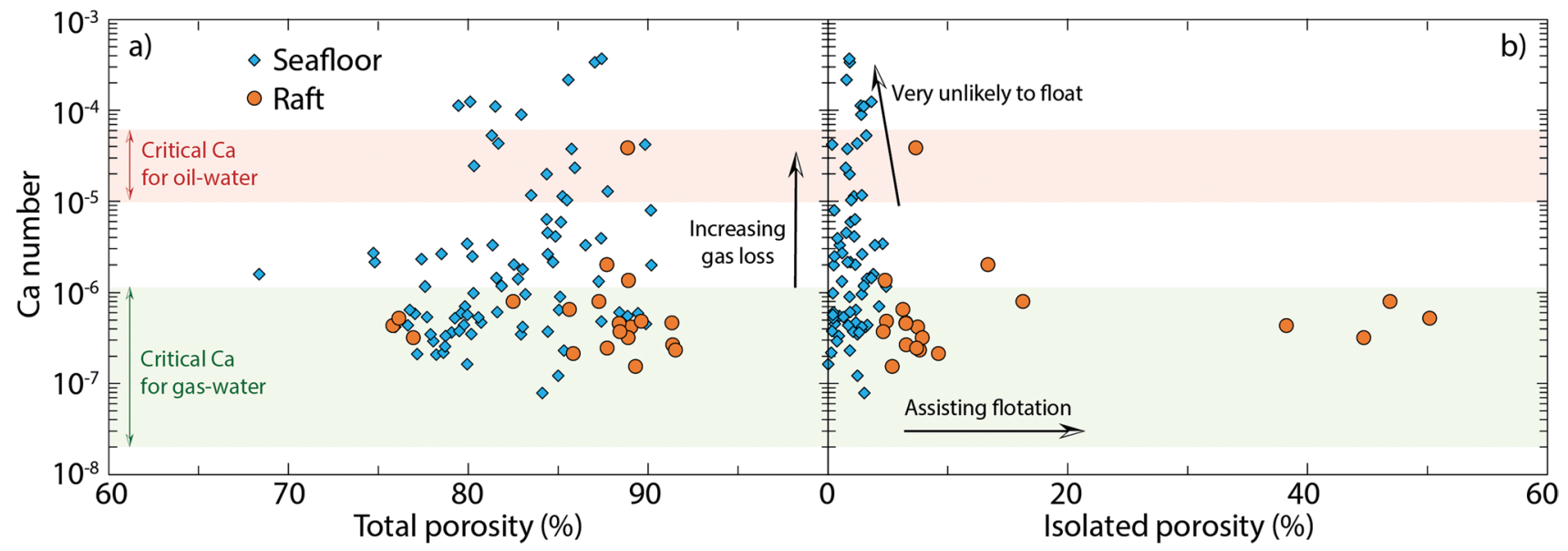

Fig. 10 Calculated Ca number for raft and seafloor pumice from permeability data vs. total (a) and isolated (b) porosity. Approximate critical Ca numbers are highlighted for capillary trapping in gas-water and oil-water systems [Ding and Kantzas 2007]
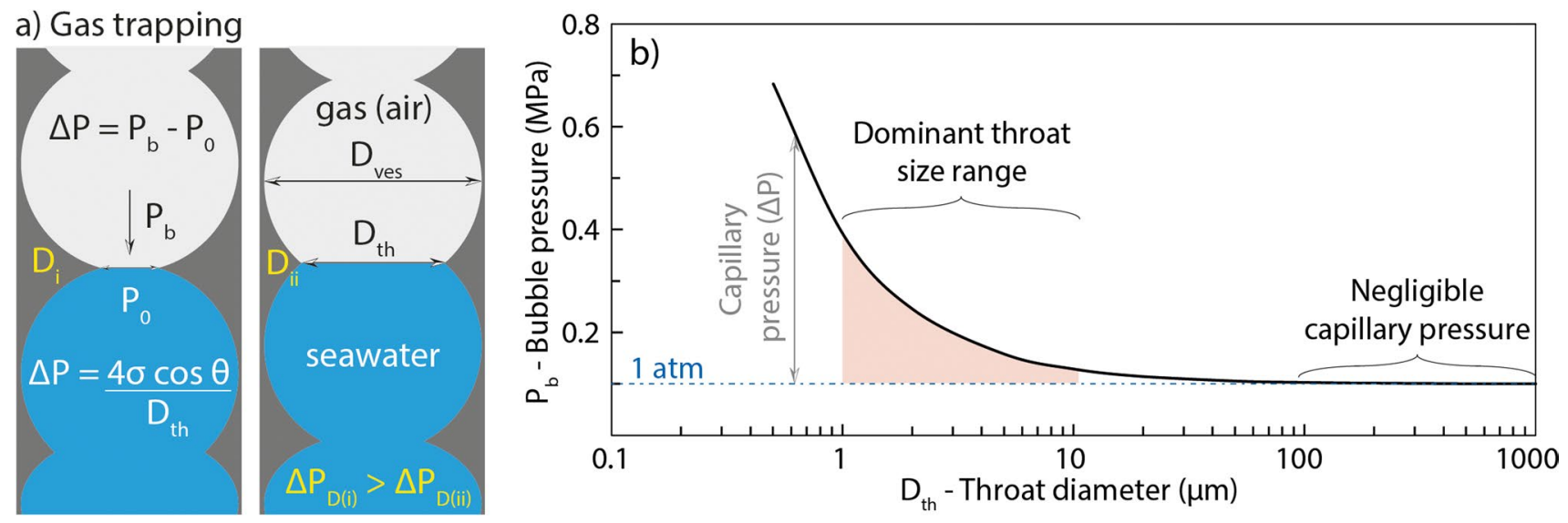

Fig. 11 a Surface (gas-liquid/air-seawater interfacial) tension $(\sigma)$ across a vesicle pore throat diameter $\left(D_{\mathrm{th}}\right)$ in capillary gas trapping. $\Delta \mathrm{P}$ is the differential (capillary) pressure between the gas $\left(\mathrm{P}_{\mathrm{b}}\right)$ and liquid pressure $\left(\mathrm{P}_{0}\right)$ acting over the interface; $\mathbf{b}$ calculated gas bubble pressure $\left(\mathrm{P}_{\mathrm{b}}\right)$ from Eq. 7 over a vesicle throat interface with changing $D_{\text {th }}$ assuming $\theta=0$. The dominant throat size range from throat analysis is given between 1 and $10 \mu \mathrm{m} .1 \mathrm{~atm}=0.1 \mathrm{MPa}$ 
et al. 2015; Cerdeira et al. 2020], Eq. 7 shows that narrowing of the bubble requires significant internal gas pressure for gas loss to occur. At very small bubble sizes $(1-10 \mu \mathrm{m})$, capillary pressure can be greater than $1 \mathrm{~atm}$ and thus sufficient to inhibit gas loss [Fig. 11b]. Equation 7 also shows how wettability $(\theta)$ has a secondary effect on the internal pressure required for a bubble to pass through a narrow constriction; we explore this further in Supplement 9. We now discuss controls on gas trapping with respect to absolute and relative pore diameter, wettability, throat geometry, and flow rate.

\section{Impact of pore structure on gas trapping}

Studies on capillary gas trapping have demonstrated that pore structure impacts the amount of trapped residual gas. Specifically, the pore-to-throat to pore-to-body ratio has been strongly linked with capillary gas trapping, with smaller throat-to-body ratios resulting in more trapped gas [Chatzis et al. 1988 1983; Jerauld and Salter 1990; Nguyen et al. 2006; Wardlaw and Yu 1988; Wardlaw 1982]. This has also been experimentally demonstrated at the mm-scale as bubble fluid flow is inhibited through narrowing constrictions, i.e., smaller throat-to-body ratios [Dawson et al. 2015].

Smaller vesicle throats and throat-to-body ratios in raft vs. seafloor clasts ( $0.25-0.47$ vs. $0.41-0.67)$ [Fig. 8e, g-h, i] are consistent with previous studies that suggest that both these pore characteristics trap more gas. To be clear, we are suggesting that it is not a coincidence that rafted clasts have, on average, smaller pore-to-throat and throat-to-body ratios than seafloor clasts. Instead, we suggest that clasts with smaller vesicle-to-throat and throat-to-body ratios trapped more residual gas and became rafted clasts and vice versa [Fig. 11a].

The subtle difference in microtextures (total porosity, vesicle connectivity, throat diameters, and throat-vesicle ratios) between high vesicularity raft pumice and high vesicularity seafloor pumice [Fig. 6b] may reflect observed natural variations in pumice textures produced from laterally heterogeneous regions of the conduit with less shearing [Houghton et al. 2010; Ohashi et al. 2021; Trafton and Giachetti 2021]. The clear connectivity separation at high vesicularity by "sink or float" may just be a case of endmember sampling bias (only raft pumice with most extreme "flotation-permitting" microtextures will still have been afloat 1 year after eruption). The lower connectivity (high isolated porosity) raft pumice may reflect magma erupted at a different stage of the eruption or differences in quenching depths and thus hindering of further vesiculation in the water column [Mitchell et al. 2019].

\section{Implications for submarine volcanology and future expeditions}

We document that isolated porosity, throat diameters, and throat-to-vesicle diameter ratios are key textural controls on the ability of pumice to trap gas and remain afloat. This is an important step forward for understanding the dispersal of pumice from submarine volcanic eruptions.

Our measurements of throat diameters also have implications for microscale pumice permeability. Permeability estimates acquired within $\mathrm{cm}$-sized cores are biased by any heterogeneities like mm-wide vesicle trains, natural fractures, or permeable pathways that transgress the entire clast; they dominate fluid flow [Contreras 2020; Vasseur et al. 2021]. Estimating permeability directly from throat measurements $1-200 \mu \mathrm{m}$ in size gives a more realistic magma permeability at the sub-mm-scale. Using the Kozeny-Carman relationship for porosity and permeability (Eq. 8) (Saar and Manga 1999), we determine the minimum clast permeability $(k)$ if all vesicle throats were of the same (monodisperse) diameter. We compare throat-calculated permeability against the acquired Havre 2012 permeability calculations [Fig. 6a] and a global compilation of rhyolite permeability-total porosity $\left(\varnothing_{t}\right)$ data by Colombier et al. (2017):

$k=\frac{D_{t h} \varnothing_{t}^{2}}{180}\left(\frac{1}{\left(1-\varnothing_{t}\right)^{2}}\right)$

The $k_{1}$ permeability values for Havre raft pumice sit between the modelled Kozeny-Carman permeabilities for monodisperse throat diameters of $\sim 2-7 \mu \mathrm{m}$, which is consistent with the average and modal throat diameters from BSE image analysis [Fig. 8]. The Havre seafloor clasts can have much higher permeabilities than seen for monodisperse pore diameters on the order of 5-100 $\mu \mathrm{m}$ [Fig. 12a]. Throats of a larger size are present in giant pumice and ALB clasts [Fig. 8i]. Mitchell et al. (2019) also identified sub-mm-thick fractures running through the whole GP290 clast; these fractures would dominate clast permeability at the $\mathrm{cm}$-scale (as measured using capillary flow porometry). Silicic lava/dome samples from other locations generally indicate permeability controlled by larger features such as permeable pathways [Fig. 12a], which is consistent with our understanding of high vesicle connectivity at low porosity and outgassing through permeable pathways in silicic lavas [Fig. 12b] [Rust and Cashman 2004; Colombier et al. 2017]. Lower porosity silicic clasts from the global dataset indicate that much lower permeabilities are constrained by very few, narrow openings between coalesced vesicles.

The global dataset of porosity measurements from subaerial and submarine silicic pumices and lavas [Colombier et al. 2017] shows just how extreme the 


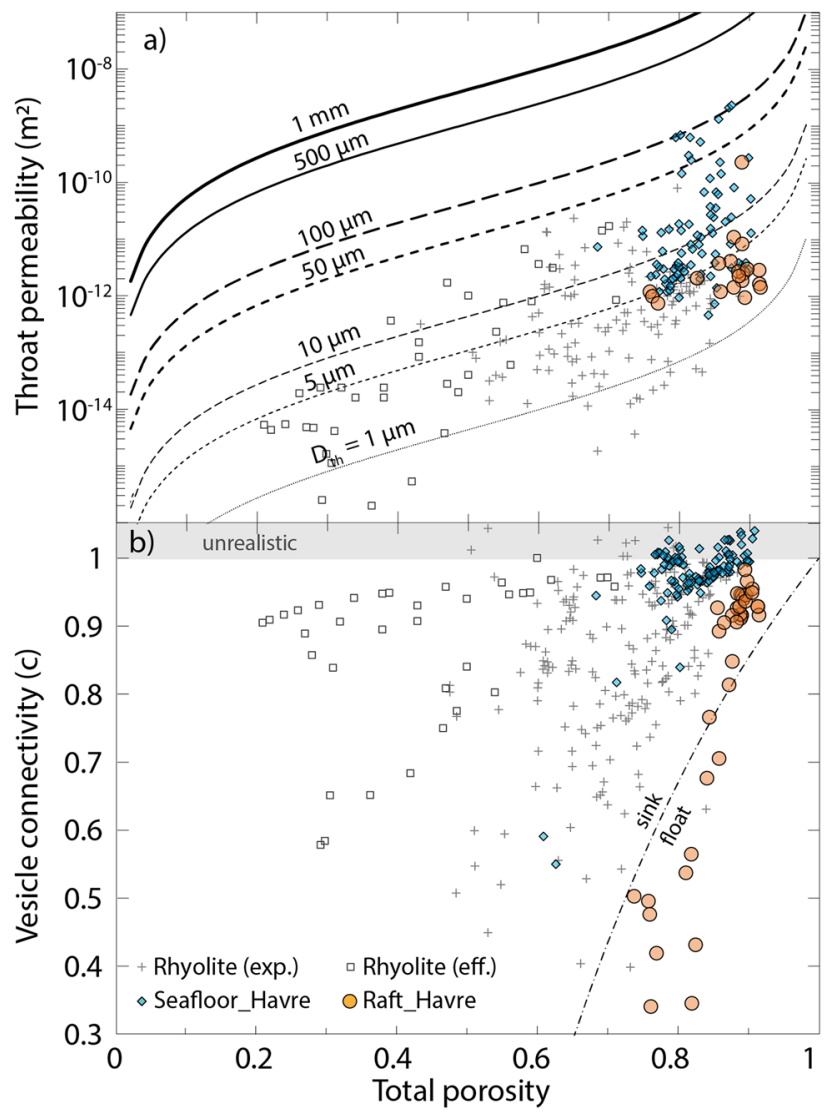

Fig. 12 a Modelled minimum clast permeability from the KozenyCarman equation [Saar and Manga 1999] as controlled by an average vesicle throat diameter $\left(D_{\text {th }}\right)$, overlain with Darcian permeability data $\left(k_{l}\right)$ for Havre raft and seafloor clasts, and global rhyolite/rhyodacite permeability-porosity data [Colombier et al. 2017]; b global rhyolite/ rhyodacite connectivity-porosity data against the new Havre raft and seafloor data (this study). The black dashed line represents $c_{t h s}$ (Eq. 3) for $s=1$; eff. $=$ effusive, exp. $=$ explosive

connectivity-porosity relationship is for the 2012 Havre raft pumice [Fig. 12b]; these pumices represent the consistently lowest vesicle connectivity values at high vesicularity currently on record. The extreme connectivity in the Havre raft pumice may not be unique, as this is the only published dataset for long-lived raft pumice from any submarine eruption. Given this, we emphasize the need to build up the suite of connectivity-porosity-permeability data for submarineerupted raft pumice from other locations; future exploratory efforts and rapid response to raft events will help in expanding this.

On a broader scale, this work demonstrates that rafted and seafloor pumice from the same eruption can exhibit fundamentally different microtextures. Sampling either raft or submarine pumice alone is not enough to fully characterize eruptive products or key parameters (e.g., mass eruption rate and total eruptive volume) from submarine eruptions. The absence of raft pumice from the submarine record can make historic deposits difficult to interpret. It is possible that previous studies of only seafloor pumice deposits have underestimated magma decompression rates, MER, and total eruptive volume, from a lack of raft pumice data to incorporate. This has significant implications for magma production rates at silicic centers along submarine volcanic arcs such as the Tonga-Kermadec, Izu-Bonin, Aegean, and South Sandwich Islands [Fiske et al. 2001; Nomikou et al. 2014; Liu et al. 2021]. Our study suggests reconsidering, and possibly reinterpreting, past observations and measurements from historic/ancient seafloor stratigraphic sequences.

The differences between raft and submarine pumice (eruptive volume, MER, and microtextural characteristics) from the 2012 Havre eruption demonstrate the value in sampling submarine deposits and raft material soon after the eruption to complement remote sensing data [Carey et al. 2018]. Increasing monitoring and rapid detection of pumice rafts by remote sensing will allow for more rapid response efforts to sample pumice rafts' coeval seafloor deposits [Vaughan and Webley; 2010; Rubin et al. 2012; Carey et al. 2014; Jutzeler et al. 2014; Brandl et al. 2019; Mittal and Delbridge 2019; Jutzeler et al. 2020; Whiteside et al. 2021]. The Havre 2012 eruption will be only the first of many fully comprehensive studies of submarine silicic volcanic eruptions.

\section{Summary}

In this study of pumice clasts from the 2012 submarine Havre eruption, we show that pumice clasts will either float or sink to the seafloor, controlled by their microtextures. This separation occurred despite the identical geochemistry, bulk porosities, eruptive vent depth and location, and proposed synchronous eruption of the pumices studied [Carey et al. 2018]. Compared to seafloor pumice, raft pumice exhibited higher vesicle number densities, smaller modal vesicle sizes, smaller and more constrained permeability values, lower vesicle connectivity (i.e., greater volumetric proportions of isolated porosity) at equivalent total porosity, smaller vesicle throat diameters, and lower vesicle-to-throat diameter ratios. Critically, we identified two distinct porosity populations within the raft pumice, where flotation was controlled by very different pore structures:

1. Lower vesicularity raft pumice $(<\sim 80 \%$ porosity) where the volume of gas-filled isolated porosity was sufficiently high to permit pumice flotation when the connected porosity was fully saturated by seawater

2. High vesicularity raft pumice $(>\sim 80 \%)$ where isolated porosity was more limited and therefore capillary gas trapping within the connected porosity was required to permit pumice flotation 
Through vesicle throat analysis, we demonstrated that smaller throat diameters and smaller throat-to-vesicle ratios favor capillary gas trapping within the raft pumices. Vesicle throat analysis is a currently underused tool in pyroclastic studies but may be critical for improving understanding of permeable fluid flow and pumice flotation.

Our data expands the current global dataset of vesicle connectivity and permeability for silicic pumices, accounting for (and improving on) a current lack of deep submarine data in volcanological literature. This study also highlights the critical need to combine sea-surface and seafloor sampling for a greater understanding of submarine pumice-producing eruptions, in particular, processes and controls of bubble nucleation and coalescence in magma.

Supplementary Information The online version contains supplementary material available at https://doi.org/10.1007/s00445-021-01497-6.

Acknowledgements We would like to thank Thomas Giachetti for conducting He pycnometry analysis at the University of Oregon, Zachary Langdalen and Warren M. McKenzie for assistance in measuring clast densities, and JoAnn Sinton and Wagner Petrographic for thin section preparation. We further acknowledge the full scientific team, crew, and Jason ROV and Sentry AUV technicians (Woods Hole Oceanographic Institute) aboard the R/V Roger Revelle (Scripps Institute of Oceanography) during the MESH expedition in 2015. A great deal of gratitude is given to Eleanor John, who solely collected hundreds of raft clasts from the shores of Fiji and sent them to the University of Hawai'i for analysis. We also thank Mattia Pistone for the valuable discussion of ideas we explored, and Mathieu Colombier, Corrado Cimarelli, and an anonymous reviewer for their valuable comments and suggestions through peer review.

Author contribution SJM conducted most of the macrotextural and microtextural analysis, with some analysis completed by those mentioned in the acknowledgments. SJM and KEF wrote the manuscript, and SJM created the figures. All authors provided edits for multiple versions of the manuscript and approved the final version for submission.

Funding SJM, BFH, RJC, and the research were supported and funded by NSF grant OCE-1357443. No other funding was used for the research.

Data availability Key data and results are included in the manuscript tables and supplementary information.

Code availability Not applicable.

\section{Declarations}

Ethics approval Not applicable.

Consent to participate Not applicable.

Consent for publication All authors approved the final version of the manuscript for submission.

Conflict of interest The authors declare no competing interests.
Open Access This article is licensed under a Creative Commons Attribution 4.0 International License, which permits use, sharing, adaptation, distribution and reproduction in any medium or format, as long as you give appropriate credit to the original author(s) and the source, provide a link to the Creative Commons licence, and indicate if changes were made. The images or other third party material in this article are included in the article's Creative Commons licence, unless indicated otherwise in a credit line to the material. If material is not included in the article's Creative Commons licence and your intended use is not permitted by statutory regulation or exceeds the permitted use, you will need to obtain permission directly from the copyright holder. To view a copy of this licence, visit http://creativecommons.org/licenses/by/4.0/.

\section{References}

Allen SR, Fiske RS, Cashman KV (2008) Quenching of steam-charged pumice: implications for submarine pyroclastic volcanism. Earth Planet Sci Lett 274(1-2):40-49. https://doi.org/10.1016/j.eps1. 2008.06.050

Bernard O, de Maisonneuve CB (2020) Controls on eruption style at Rabaul, Papua New Guinea-insights from microlites, porosity and permeability measurements. J Volcanol Geoth Res 406:107068. https://doi.org/10.1016/j.jvolgeores.2020.107068

Blunt MJ, Scher H (1995) Pore-level modeling of wetting. Phys Rev E 52(6):6387. https://doi.org/10.1103/PhysRevE.52.6387

Bouvet de Maisonneuve CB, Bachmann O, Burgisser A (2009) Characterization of juvenile pyroclasts from the Kos Plateau Tuff (Aegean Arc): insights into the eruptive dynamics of a large rhyolitic eruption. Bull Volcanol 71(6):643-658. https://doi.org/10. 1007/s00445-008-0250-x

Brandl PA Schmid F Augustin N Grevemeyer I Arculus RJ Devey CW Petersen S Stewart M Kopp H, Hannington MD 2019 The 6-8 Aug 2019 eruption of 'Volcano F' in the Tofua Arc, Tonga. J Volcanol Geotherm Res , p.106695, https://doi.org/10.1016/j. jvolgeores.2019.106695

Bryan SE, Cook A, Evans JP, Colls PW, Wells MG, Lawrence MG, Jell JS, Greig A, Leslie R (2004) Pumice rafting and faunal dispersion during 2001-2002 in the Southwest Pacific: record of a dacitic submarine explosive eruption from Tonga. Earth Planet Sci Lett 227(1-2):135-154. https://doi.org/10.1016/j.eps1.2004.08.009

Bryan SE, Cook AG, Evans JP, Hebden K, Hurrey L, Colls P, Jell JS, Weatherley D, Firn J (2012) Rapid, long-distance dispersal by pumice rafting. PLoS ONE 7(7):e40583. https://doi.org/10.1371/ journal.pone.0040583

Carey RJ, Wysoczanski R, Wunderman R, Jutzeler M (2014) Discovery of the largest historic silicic submarine eruption. EOS Trans Am Geophys Union 95(19):157-159. https://doi.org/10.1002/2014E O190001

Carey RJ, Soule SA, Manga M, White JDL, McPhie J, Wysoczanski R, Jutzeler M, Tani K, Fornari D, Caratori-Tontini F, Houghton BF, Mitchell SJ, Ikegami F, Conway C, Murch A, Fauria K, Jones M, Cahalan R, McKenzie W (2018) The largest deep-ocean silicic volcanic eruption of the past century. Sci Adv 4(1):e1701121. https://doi.org/10.1126/sciadv.1701121

Cas RA, Simmons J (2018) Why deep-water eruptions are so different from subaerial eruptions. Front Earth Sci 6:198. https://doi.org/ 10.3389/feart.2018.00198

Cashman KV, Fiske RS (1991) Fallout of pyroclastic debris from submarine volcanic eruptions. Science 253(5017):275-280. https:// doi.org/10.1126/science.253.5017.275 
Cashman KV, Sparks RSJ 2013 How volcanoes work: a 25 year perspective. Bulletin, 125(5-6), pp. 664-690, https://doi.org/10.1130/ B30720.1

Cassidy M, Manga M, Cashman K, Bachmann O (2018) Controls on explosive-effusive volcanic eruption styles. Nat Commun 9(1):2839. https://doi.org/10.1038/s41467-018-05293-3

Cerdeira AT, Campos JB, Miranda JM, Araújo JD (2020) Review on microbubbles and microdroplets flowing through microfluidic geometrical elements. Micromachines 11(2):201. https://doi.org/ 10.3390/mi11020201

Chao C, Xu G, Fan X (2019) Effect of surface tension, viscosity, pore geometry and pore contact angle on effective pore throat. Chem Eng Sci 197:269-279. https://doi.org/10.1016/j.ces.2018.12.029

Chatzis I, Morrow NR, Lim HT (1983) Magnitude and detailed structure of residual oil saturation. Soc Petrol Eng J 23(02):311-326. https://doi.org/10.2118/10681-PA

Chatzis I, Kuntamukkula MS, Morrow NR (1988) Effect of capillary number on the microstructure of residual oil in strongly water-wet sandstones. SPE Reserv Eng 3(03):902-912. https://doi.org/10. 2118/13213-PA

Colombier M, Wadsworth FB, Gurioli L, Scheu B, Kueppers U, Di Muro A, Dingwell DB (2017) The evolution of pore connectivity in volcanic rocks. Earth Planet Sci Lett 462:99-109. https://doi. org/10.1016/j.eps1.2017.01.011

Colombier M, Wadsworth FB, Scheu B, Vasseur J, Dobson KJ, Cáceres F, Allabar A, Marone F, Schlepütz CM, Dingwell DB (2020) In situ observation of the percolation threshold in multiphase magma analogues. Bull Volcanol 82(4):1-15. https://doi.org/10. 1007/s00445-020-1370-1

Colombier M, Vasseur J, Houghton BF, Cáceres F, Scheu B, Kueppers U, Thivet S, Gurioli L, Montanaro C, Soldati A, Di Muro A (2021) Degassing and gas percolation in basaltic magmas. Earth Planet Sci Lett 573:117134. https://doi.org/10.1016/j.epsl.2021. 117134

Contreras C (2020) Silicic eruptive transitions of Laguna Del Maule Doctoral dissertation. University of Bristol

Dawson G, Häner E, Juel A (2015) Extreme deformation of capsules and bubbles flowing through a localised constriction. Procedia IUTAM 16:22-32. https://doi.org/10.1016/j.piutam.2015.03.004

DeGraffenried RL, Larsen JF, Graham NA, Cashman KV (2019) The influence of phenocrysts on degassing in crystal-bearing magmas with rhyolitic groundmass melts. Geophys Res Lett 46(10):51275136. https://doi.org/10.1029/2018GL081822

Degruyter W, Bachmann O, Burgisser A, Manga M (2012) The effects of outgassing on the transition between effusive and explosive silicic eruptions. Earth Planet Sci Lett 349:161-170. https://doi. org/10.1016/j.eps1.2012.06.056

Ding M, Kantzas A 2007 Capillary number correlations for gas-liquid systems. J Can Pet Technol 46(02), https://doi.org/10.2118/ 07-02-03

Fauria KE, Manga M, Wei Z (2017) Trapped bubbles keep pumice afloat and gas diffusion makes pumice sink. Earth Planet Sci Lett 460:50-59. https://doi.org/10.1016/j.eps1.2016.11.055

Fauria KF, Manga M (2018) Pyroclast cooling and saturation in water. J Volcanol Geoth Res 352:17-31. https://doi.org/10.1016/j.jvolg eores.2018.07.002

Fiske RS, Naka J, Iizasa K, Yuasa M, Klaus A (2001) Submarine silicic caldera at the front of the Izu-Bonin arc, Japan: voluminous seafloor eruptions of rhyolite pumice. Geol Soc Am Bull 113(7):813-824. https://doi.org/10.1130/0016-7606(2001)113\% 3c0813:SSCATF\%3e2.0.CO;2

Gass IG, Harris PG, Holdgate MW (1963) Pumice eruption in the area of the South Sandwich Islands. Geol Mag 100(4):321-330. https:// doi.org/10.1017/S0016756800056053

Giachetti T, Gonnermann HM, Gardner JE, Burgisser A, Hajimirza S, Earley TC, Truong N, Toledo P (2019) Bubble coalescence and percolation threshold in expanding rhyolitic magma. Geochem Geophys Geosyst 20(2):1054-1074. https://doi.org/10.1029/ 2018GC008006

Guo H, Dou M Hanqing W, Wang F, Yuanyuan G, Yu Z, Yansheng W, Li Y 2015 Review of capillary number in chemical enhanced oil recovery. In SPE Kuwait Oil and Gas Show and Conference. OnePetro, https://doi.org/10.2118/175172-MS

Hilfer R, Øren PE (1996) Dimensional analysis of pore scale and field scale immiscible displacement. Transp Porous Media 22(1):5372. https://doi.org/10.1007/BF00974311

Houghton BF, Wilson C (1989) A vesicularity index for pyroclastic deposits. Bull Volcanol 51(6):451-462. https://doi.org/10.1007/ BF01078811

Houghton B, Carey RJ (2015) Pyroclastic fall deposits. In The Encyclopedia of Volcanoes (pp. 599-616). Academic Press

Houghton BF, Carey RJ, Cashman KV, Wilson CJ, Hobden BJ, Hammer JE (2010) Diverse patterns of ascent, degassing, and eruption of rhyolite magma during the $1.8 \mathrm{ka}$ Taupo eruption, New Zealand: evidence from clast vesicularity. Journal of Volcanology and Geothermal Research 195(1):31-47. https://doi.org/10. 1016/j.jvolgeores.2010.06.002

Hu Y, She Y, Patmonoaji A, Zhang C, Suekane T (2020) Effect of capillary number on morphological characterizations of trapped gas bubbles: study by using micro-tomography. Int J Heat Mass Transf 163:120508. https://doi.org/10.1016/j.ijheatmasstransfer. 2020.120508

Ikegami F, McPhie J, Carey R, Mundana R, Soule A, Jutzeler M (2018) The eruption of submarine rhyolite lavas and domes in the deep ocean-Havre 2012. Kermadec Arc Frontiers in Earth Science 6:147. https://doi.org/10.3389/feart.2018.00147

Jerauld GR, Salter SJ (1990) The effect of pore-structure on hysteresis in relative permeability and capillary pressure: pore-level modeling. Transp Porous Media 5(2):103-151. https://doi.org/ 10.1007/BF00144600

Jutzeler M, Marsh R, Carey RJ, White JD, Talling PJ, Karlstrom L 2014 On the fate of pumice rafts formed during the 2012 Havre submarine eruption. Nature communications, 5, pp. 3660(1-9), https://doi.org/10.1038/ncomms4660

Jutzeler M, Marsh R, van Sebille E, Mittal T, Carey RJ, Fauria KE, Manga M, McPhie J (2020) Ongoing dispersal of the 7 August 2019 pumice raft from the Tonga arc in the southwestern Pacific Ocean. Geophys Res Lett 47(5):e1701121. https://doi.org/10. 1029/2019GL086768

Krevor S, Blunt MJ, Benson SM, Pentland CH, Reynolds C, AlMenhali A, Niu B (2015) Capillary trapping for geologic carbon dioxide storage-from pore scale physics to field scale implications. Int J Greenhouse Gas Control 40:221-237. https://doi.org/ 10.1016/j.ijggc.2015.04.006

Lindoo A, Larsen JF, Cashman KV, Dunn AL, Neill OK (2016) An experimental study of permeability development as a function of crystal-free melt viscosity. Earth Planet Sci Lett 435:45-54. https://doi.org/10.1016/j.epsl.2015.11.035

Lindoo A, Larsen JF, Cashman KV, Oppenheimer J (2017) Crystal controls on permeability development and degassing in basaltic andesite magma. Geology 45(9):831-834. https://doi.org/ 10.1130/G39157.1

Liu EJ, Wood K, Aiuppa A, Giudice G, Bitetto M, Fischer TP, Kilbride BTM, Plank T, Hart T (2021) Volcanic activity and gas emissions along the South Sandwich Arc. Bull Volcanol 83(1):1-23. https://doi.org/10.1007/s00445-020-01415-2

Manga M, Fauria KE, Lin C, Mitchell SJ, Jones M, Conway CE, Degruyter W, Hosseini B, Carey R, Cahalan R, Houghton BF (2018a) The pumice raft-forming 2012 Havre submarine eruption was effusive. Earth Planet Sci Lett 489:49-58. https://doi. org/10.1016/j.epsl.2018.02.025 
Manga M, Mitchell SJ, Degruyter W, Carey RJ 2018b Transition of eruptive style: pumice raft to dome-forming eruption at the Havre submarine volcano. Geology, 46(20), https://doi.org/10. $1130 / \mathrm{G} 45436.1$

Martí J, Groppelli G, da Silveira AB (2018) Volcanic stratigraphy: a review. J Volcanol Geoth Res 357:68-91. https://doi.org/10. 1016/j.jvolgeores.2018.04.006

Millero FJ, Huang F (2009) The density of seawater as a function of salinity ( 5 to $70 \mathrm{~g} \mathrm{~kg}^{-1}$ ) and temperature $(273.15$ to $363.15 \mathrm{~K})$. Ocean Sci 5(2):91-100. https://doi.org/10.5194/os-5-91-2009

Mitchell SJ (2018) Deep submarine silicic volcanism: conduit and eruptive dynamics of the 2012 Havre eruption. Doctoral dissertation, University of Hawai at Manoa

Mitchell SJ, McIntosh IM, Houghton BF, Carey RJ, Shea T (2018) Dynamics of a powerful deep submarine eruption recorded in $\mathrm{H}_{2} \mathrm{O}$ contents and speciation in rhyolitic glass: the 2012 Havre eruption. Earth Planet Sci Lett 494:135-147. https://doi.org/10. 1016/j.eps1.2018.04.053

Mitchell SJ, Houghton BF, Carey RJ, Manga M, Fauria KE, Jones MR, Soule SA, Conway CE, Wei Z, Giachetti T (2019) Submarine giant pumice: a window into the shallow conduit dynamics of a recent silicic eruption. Bull Volcanol 81(7):42. https://doi.org/10. 1007/s00445-019-1298-5

Mittal T, Delbridge B (2019) Detection of the 2012 Havre submarine eruption plume using Argo floats and its implications for ocean dynamics. Earth Planet Sci Lett 511:105-116. https://doi.org/10. 1016/j.eps1.2019.01.035

Murch AP, White JD, Carey RJ (2019) Characteristics and deposit stratigraphy of submarine-erupted silicic ash, Havre Volcano, Kermadec Arc, New Zealand. Frontiers in Earth Science 7:1-21. https://doi.org/10.3389/feart.2019.00001

Murch AP, White JDL, Carey RJ (2019b) Unusual fluidal behavior of a silicic magma during fragmentation in a deep subaqueous eruption, Havre volcano, southwestern Pacific Ocean. Geology 47(5):487-490. https://doi.org/10.1130/G45657.1

Nguyen VH, Sheppard AP, Knackstedt MA, Pinczewski WV (2006) The effect of displacement rate on imbibition relative permeability and residual saturation. J Petrol Sci Eng 52(1-4):54-70. https:// doi.org/10.1016/j.petrol.2006.03.020

Nomikou P, Carey S, Bell KLC, Papanikolaou D, Bejelou K, Cantner K, Sakellariou D, Perros I (2014) Tsunami hazard risk of a future volcanic eruption of Kolumbo submarine volcano, NE of Santorini Caldera. Greece Natural Hazards 72(3):1375-1390. https:// doi.org/10.1007/s11069-012-0405-0

Ohashi M, Ichihara M, Kennedy B, Gravley D 2021 Comparison of bubble shape model results with textural analysis: implications for the velocity profile across a volcanic conduit. Journal of Geophysical Research: Solid Earth, p.e2021JB021841, https://doi.org/ 10.1029/2021JB021841

Okumura S, Nakamura M, Uesugi K, Nakano T, Fujioka T (2013) Coupled effect of magma degassing and rheology on silicic volcanism. Earth Planet Sci Lett 362:163-170. https://doi.org/10.1016/j.epsl. 2012.11.056

Øren PE, Ruspini LC, Saadatfar M, Sok RM, Knackstedt M, Herring A (2019) In-situ pore-scale imaging and image-based modelling of capillary trapping for geological storage of $\mathrm{CO} 2$. Int J Greenhouse Gas Control 87:34-43. https://doi.org/10.1016/j.ijggc.2019.04.017

Pistone M, Caricchi L, Ulmer P (2021) CO2 favours the accumulation of excess fluids in felsic magmas. Terra Nova 33(2):120-128. https://doi.org/10.1111/ter.12496

Pyle DM (1989) The thickness, volume and grainsize of tephra fall deposits. Bull Volcanol 51(1):1-15. https://doi.org/10.1007/ BF01086757
Risso C, Scasso RA, Aparicio A (2002) Presence of large pumice blocks on Tierra del Fuego and South Shetland Islands shorelines, from 1962 South Sandwich Islands eruption. Mar Geol 186(3):413-422. https://doi.org/10.1016/S0025-3227(02)00190-1

Rotella MD, Wilson CJ, Barker SJ, Schipper CI, Wright IC, Wysoczanski RJ (2015) Dynamics of deep submarine silicic explosive eruptions in the Kermadec arc, as reflected in pumice vesicularity textures. J Volcanol Geoth Res 301:314-332. https://doi.org/10. 1016/j.jvolgeores.2015.05.021

Rubin KH, Soule SA, Chadwick WW Jr, Fornari DJ, Clague DA, Embley RW, Baker ET, Perfit MR, Caress DW, Dziak RP (2012) Volcanic eruptions in the deep sea. Oceanography 25(1):142-157

Rust AC, Cashman KV (2004) Permeability of vesicular silicic magma: inertial and hysteresis effects. Earth Planet Sci Lett 228(1):93107. https://doi.org/10.1016/j.epsl.2004.09.025

Saar MO, Manga M (1999) Permeability-porosity relationship in vesicular basalts. Geophys Res Lett 26(1):111-114. https://doi.org/10. 1029/1998GL900256

Sahagian DL, Proussevitch AA (1998) 3D particle size distributions from 2D observations: stereology for natural applications. J Volcanol Geoth Res 84(3-4):173-196. https://doi.org/10.1016/ S0377-0273(98)00043-2

Schindelin J, Arganda-Carreras I, Frise E, Kaynig V, Longair M, Pietzsch T, Preibisch S, Rueden C, Saalfeld S, Schmid B, Tinevez JY (2012) Fiji: an open-source platform for biological-image analysis. Nat Methods 9(7):676-682. https://doi.org/10.1038/nmeth.2019

Shea T, Houghton BF, Gurioli L, Cashman KV, Hammer JE, Hobden BJ (2010) Textural studies of vesicles in volcanic rocks: an integrated methodology. J Volcanol Geoth Res 190:271-289. https:// doi.org/10.1016/j.jvolgeores.2009.12.003

Stewart AL, McPhie J (2004) An Upper Pliocene coarse pumice breccia generated by a shallow submarine explosive eruption, Milos. Greece Bulletin of Volcanology 66(1):15-28

Trafton KR, Giachetti T (2021) The morphology and texture of Plinian pyroclasts reflect their lateral sourcing in the conduit. Earth Planet Sci Lett 562:116844. https://doi.org/10.1016/j.epsl.2021.116844

Valvatne PH, Blunt MJ 2004 Predictive pore-scale modeling of twophase flow in mixed wet media. Water Resour Res, 40(7), https:// doi.org/10.1029/2003WR002627

Vaughan RG, Abrams MJ, Hook SJ, Pieri DC (2007) Satellite observations of new volcanic island in Tonga. EOS Trans Am Geophys Union 88(4):37-41. https://doi.org/10.1029/2007EO040002

Vaughan RG, Webley PW (2010) Satellite observations of a Surtseyan eruption: Hunga Ha'apai, Tonga. J Volcanol Geoth Res 198(12):177-186. https://doi.org/10.1029/2007EO040002

Vasseur J, Wadsworth FB, Coumans JP, Dingwell DB (2021) Permeability of packs of polydisperse hard spheres. Phys Rev E 103(6):062613. https://doi.org/10.1103/PhysRevE.103.062613

Wardlaw NC 1982 The effects of geometry, wettability, viscosity and interfacial tension on trapping in single pore-throat pairs. J Can Pet Technol, 21(03), https://doi.org/10.2118/82-03-01

Wardlaw NC, Yu L (1988) Fluid topology, pore size and aspect ratio during imbibition. Transp Porous Media 3(1):17-34. https://doi. org/10.1007/BF00222684

Whiteside A, Dupouy C, Singh A, Frouin R, Menkes C, Lefèvre J (2021) Automatic detection of optical signatures within and around floating Tonga-Fiji pumice rafts using MODIS, VIIRS, and OLCI Satellite Sensors. Remote Sensing 13(3):501. https:// doi.org/10.3390/rs13030501 